Article

\title{
Allometries for Widely Spaced Populus ssp. and Betula ssp. in Nurse Crop Systems
}

\author{
Hendrik Stark $^{1, *}$, Arne Nothdurft ${ }^{2}$ and Jürgen Bauhus ${ }^{1}$ \\ ${ }^{1}$ Chair of Silviculture, Faculty of Environment and Natural Resources, University of Freiburg, \\ Tennenbacherstr. 4, Freiburg 79085, Germany; E-Mail: juergen.bauhus@waldbau.uni-freiburg.de \\ ${ }^{2}$ Department of Biometrics and Informatics, Forest Research Institute Baden-Württemberg, \\ Wonnhaldestr. 4, Freiburg 79100, Germany; E-Mail: arne.nothdurft@ forst.bwl.de \\ * Author to whom correspondence should be addressed; E-Mail: hendrik.stark@gmx.net; \\ Tel.: +49-761-2038619.
}

Received: 8 September 2013; in revised form: 6 November 2013 / Accepted: 6 November 2013 / Published: 22 November 2013

\begin{abstract}
Nurse crops of widely spaced pioneer trees are a silvicultural approach to protect the regeneration of frost sensitive target tree species. If overstorey nurse crops are harvested, they can provide additional short-term benefits through increased biomass production, e.g., for bioenergy. However, the intensification of biomass exports from forests might impact negatively on ecosystem nutrient pools. Thus, precise allometric biomass equations are required to quantify biomass and nutrient removals. Since an analysis of published allometric equations developed for typical, dense aspen or birch forests showed that the tree height-to-diameter ratio correlated positively and the proportion of branch biomass negatively with stand density, we developed new allometric biomass equations for widely spaced aspen and birch growing at $4 \times 4 \mathrm{~m}$ spacing. These equations yielded a root mean squared error of $13 \%$ when predicting total aboveground woody biomass for our sample trees. In contrast, the corresponding root mean squared error produced by allometric biomass equations from the literature ranged between $17 \%$ to $106 \%$ of actual dry biomass. Our results show that specific allometric biomass equations are needed for widely spaced pioneer trees both for accurate estimates of biomass and the nutrients contained within.
\end{abstract}

Keywords: allometric biomass equation; nurse crop; Populus ssp.; Betula ssp.; wide tree spacing; $\mathrm{h} / \mathrm{d}$ ratio; branch biomass allocation 


\section{Introduction}

European and national policies promote the production and use of renewable energies to support climate change mitigation. Energy from woody biomass is considered a crucial component within the set of possible renewable energies [1]. Expansion of short rotation coppice plantations (SRC) on agricultural land was proposed as one approach to increase biomass production [1,2], but for a number of reasons, this production system is currently not attractive to farmers in central Europe [3], and the competition with food production is in many situations not desirable [4,5]. Therefore, it has been suggested to intensify the provision of woody biomass from forests [5]. This may take place in conventional forest stands through increased removals or on areas specifically dedicated to increased biomass production.

Fast growing tree species suitable for rapid biomass production require large open areas, which are typically avoided in close-to-nature oriented forest management of central Europe [6]. However, storms, droughts, or pest insect outbreaks increasingly often result in large scale forest disturbance $[7,8]$. Large open areas created by these disturbances require restoration with site adapted tree species [9] and at the same time might be used to cultivate a crop of fast growing tree species to produce additional biomass $[10,11]$.

Nurse crop (NC) systems can be one way to combine these restoration and production goals. They comprise a temporal nurse crop overstorey of fast growing, early successional tree species, as well as an understory of shade-tolerant target tree species, which is typically established after the sheltering canopy of the nurse crop has developed [11-13]. Nurse crops are particularly useful in places, where large forest gaps are prone to extreme temperature and moisture regimes [14] to moderate micro-climatic conditions and thus facilitate the establishment and growth of more sensitive target tree species [15-17]. Once the nurse crop understorey trees have successfully established the biomass of the overstorey nurse crop trees may be harvested to release the target tree species from the competition of the overstorey.

Nurse crop management, biomass utilisation, and especially carbon sequestration estimates and nutrient sustainability considerations in forests require reliable information on the biomass storage and its distribution across various biomass compartments in trees [18-20]. For this purpose numerous yield tables and allometric biomass equations have been developed for commercially important tree species [21-26].

However, yield tables and biomass allometries of early successional tree species such as Populus ssp. or Betula ssp., typical overstorey species in nurse crop stands, are few for Central Europe. Most of the studies dealing with Populus ssp. or Betula ssp. have been conducted in Canada, Finland, Sweden, or the USA owing to their commercial importance in these countries. The use and extrapolation of such allometric biomass equations from these situations to nurse crop systems in central Europe was questionable owing to differences in silvicultural treatments, genetics, or site conditions [27-29]. In addition, these studies from other regions focussed mostly on young forest stands aged between 3 to 10 years, with diameters at breast height between 1 to $10 \mathrm{~cm}$, and stand densities around 10,000 stems per hectare. In contrast, the nurse crops assessed in this study were 19 years old, their diameters at breast height ranged between 10 and $30 \mathrm{~cm}$, and the stand density was about 500 to 600 trees per hectare. 
Trees in dense forests are exposed to intensive competition for light and other resources and thus typically allocate a high proportion of carbon to height growth to reach the top of the canopy [30]. In contrast and regardless of their height, trees in widely spaced forests have nearly unrestricted access to solar radiation, and thus allocate a larger proportion of carbon to the lateral development of branches and to radial stem growth [31,32]. Thus, allometric relationships reflect the adaptation of tree individuals to their environment [19]. As a consequence, one might expect the single tree stem biomass to be overestimated but branch biomass to be underestimated in widely spaced trees when applying allometric biomass equations developed for forests of higher stand density. Because branch biomass is usually rich in nutrients, its underestimation directly results in the underestimation of nutrient losses per unit exported biomass [33]. Hence, it is unclear how accurate existing allometric biomass equations from high density forests can estimate tree biomass in low density forests such as nurse crops.

Therefore, the objective of this study was to assess whether prediction of biomass for widely spaced trees typically found in nurse crops requires different allometric biomass equations from those provided in the literature.

We used a wide range of data from the literature to study this density effect in particular on the height-to-diameter ratio ( $\mathrm{h} / \mathrm{d}$ ratio) [27,34] and the proportion of branch biomass [32] of Betula ssp. (birch) and Populus ssp. (aspen) trees, which often dominate young forests following disturbance [35] or abandoning of agricultural land management [36]. We then developed allometric biomass equations for aspen and birch trees growing in widely spaced nurse crops. We fitted different equations to the four biomass compartments total aboveground woody biomass, stem wood, stem bark, and branches. We also developed allometric biomass equations for young Quercus ssp. trees growing in the understory of nurse crops. Eventually, we tested the precision of allometric biomass equations from the literature when applied to our sample trees from widely spaced nurse crops. Hence, this paper is the first of its kind to provide the required information for future biomass production and sustainability assessment in low density nurse crops.

\section{Materials and Methods}

\subsection{Study Area and Forests}

The nurse crop systems analysed in this study were established in 1991 following large scale wind-throw of pure stands of Norway spruce (Picea abies (L.) Karst.) [13]. Originally, the trial intended to examine the effects of nurse crops on the establishment, survival, and quality of target tree species at frost-prone sites. To allow for the comparison between nurse crop systems and traditional restoration methods, control plots were established and directly replanted with pure stands of the target tree species, in this case Quercus ssp. 
The present study focussed on the two sites Kirchberg (K) and Sobernheim (S). The sites were located approximately 50 kilometres apart from each other at 450 and $420 \mathrm{~m}$ a.s.1., respectively, within the Hunsrück mountain region in the German federal state of Rhineland-Palatinate.

Mean annual air temperatures (1988 until 2011) were $8.1^{\circ} \mathrm{C}$ in Kirchberg and $9.0^{\circ} \mathrm{C}$ in Sobernheim with a mean air temperature during the vegetation season (daily average temperature $>5^{\circ} \mathrm{C}$ ) of 12.4 and $13.0^{\circ} \mathrm{C}$ in Kirchberg and Sobernheim, respectively. Mean annual precipitation (2002 until 2011) was $836.5 \mathrm{~mm}$ in Kirchberg and $613.8 \mathrm{~mm}$ in Sobernheim, with $66 \%$ and $69 \%$ of the annual precipitation occurring during the vegetation season, respectively [37] (data unpublished).

Both sites were characterised by periodically water logged soils identified as Pseudogley in Kirchberg and Cambisol-Pseudogley in Sobernheim. Mean soil acidity $(\mathrm{pH})$ was 3.8 and 3.6, mean cation exchange capacity (CEC) was 71.4 and $68.2 \mu \mathrm{mol}-\mathrm{c} / \mathrm{g}$, and mean base cation saturation was $14.3 \%$ and $17.0 \%$ in Kirchberg and Sobernheim, respectively.

The nurse crop experiments comprised in the overstorey pure plots of hybrid aspen (Populus tremula L. $\times$ Populus tremuloides Michx. "Astria") and hybrid birch (Betula pendula Roth $\times$ Betula pubescens Ehrh.) in Kirchberg and pure plots of hybrid aspen and common birch (Betula pendula Roth) in Sobernheim. These treatments will be referred to in the following simply as aspen and birch regardless of the specific species or hybrid. The understoreys of nurse crop plots as well as the control plots were established with Quercus robur L. in Kirchberg and Quercus petraea (Mattuschka) Liebl. on better drained soils in Sobernheim [38]. If necessary, possible effects that hybridization may have on tree height or diameter at breast height were analysed and accounted for within the modelling process. Any trees from the Quercus ssp. sections were called "oak"; if necessary, we differentiated between "oak mono" representing the control plots and 'oak under nurse crops' representing oak planted under a nurse crop shelter.

At each of the two study sites, two plots of aspen and two sample plots of birch nurse crop system, as well as four plots of oak monoculture were installed; a total of 16 plots. Aspen and birch nurse crops were underplanted with oak in 1996. Plots were of quadratic shape with a side length of $25 \mathrm{~m}$ for aspen and $50 \mathrm{~m}$ for birch nurse crop systems and 25 or $50 \mathrm{~m}$ for oak monocultures.

At establishment, seedlings of aspen and birch were 2 years old and planted at a spacing of $4 \times 4 \mathrm{~m}$. Understorey oak seedlings were 5 and 3 years old and planted at $4 \times 1.5 \mathrm{~m}$ and $4 \times 1 \mathrm{~m}$ spacing in Sobernheim and Kirchberg, respectively; planting rows were parallel to nurse crop rows and offset by $2 \mathrm{~m}$. Monoculture oak stands were planted in two ways: five out of eight stands were established using 2 year old standard seedlings with a plant spacing of $1.5 \times 0.7 \mathrm{~m}$, and three stands were established using larger seedlings with a $2 \times 1 \mathrm{~m}$ spacing (Kirchberg 3 years; Sobernheim 5 years). However, we found (results not shown) that these two different spacings had no significant effect on yield and allocation of biomass at the time of sampling.

Hence, we compared only oak monocultures with 10,000 seedlings per hectare with plantings of oak (2500 seedlings per ha) beneath a nurse crop of 650 trees per hectare. 


\subsection{Biomass Sampling}

Diameter at breast height (dbh) was measured for all aspen and birch trees as well as for all oak trees growing on a diagonal plot transect of $2 \mathrm{~m}$ width. At each plot, five aspen, birch, or oak trees were destructively sampled. In addition to recording diameter at breast height and height of those trees, stem discs were extracted at $2 \mathrm{~m}$ intervals for aspen and birch. The length of oak stems with a diameter larger than $4 \mathrm{~cm}$ was divided by six and stem discs were extract at these relative intervals. Three branches were sampled from the lower, middle, and upper crown sections, respectively.

For each sample tree, the fresh weight was recorded for all branches, stem sections, and discs. For stem discs, fresh weight was recorded separately for wood and bark. Stem bark and sample branches were then chipped for further treatment. Finally, all samples were oven dried at $40{ }^{\circ} \mathrm{C}$ until weight constancy.

We used the mean stem wood-to-stem bark ratio, which was calculated from our fresh sample discs, to calculate the wood and bark biomass of the respective tree section. We then used a mean dry-to-fresh weight ratio to calculate the dry weight of all tree components.

For oaks growing in the understorey of nurse crops, only the total aboveground woody biomass was measured.

\subsection{Supportive Information from the Literature}

To test for the effect of stand density on allometric relationships in aspen and birch, we studied the effect of stand density on the tree height-to-diameter ratio and the allocation of branch biomass. Additionally, we studied the performance of published allometric biomass equations developed for stands of higher density ( $>650 \mathrm{~N} / \mathrm{ha}$ ) when applied to our sample trees.

For that purpose we compiled stand level data and allometric biomass equations from the literature. We searched the internet for publications using the key words "Populus ssp.", "Betula ssp.", “Quercus ssp.", "aspen”, "birch”, “oak”, "tree height”, “dbh”, "stand density”, "tree allometry", "dry weight", "biomass equation”, "biomass", "aboveground", "biomass compartments", "biomass production", and various combinations of several words, respectively.

From each publication we collected information on stand age, mean tree height, mean diameter at breast height, stand density, study location, allometric biomass equations, respective parameters, and correction factors.

Some publications report detailed information for each replicate stand analysed, whereas only summary results can be found in others. In total, 58 allometric biomass equations developed for trees in Canada, China, Estonia, Finland, Germany, USA, and Sweden were consulted (Table 1). This literature review may not be complete, but we obtained a sufficient number of studies to analyse general trends related to our research question in a global context. 
Table 1. Allometric biomass equations and parameters (a, b, c) compiled from the literature as used in this study.

\begin{tabular}{|c|c|c|c|c|c|c|}
\hline Publication & Compartment & Species & Allometric equation & a & b & c \\
\hline André (2010) et al. [39] & TotalAboveground & Q. petraea & $a \times(\pi \times d b h)^{b}$ & 0.009 & 2.428 & n.a. \\
\hline Fatemi (2011) et al. [40] & TotalAboveground & B. papyrifera & $10^{\left(a+b \times \log _{10}(d b h)\right)}$ & 1.99 & 2.538 & n.a. \\
\hline Fatemi (2011) et al. [40] & StemWood & B. papyrifera & $10^{\left(a+b \times \log _{10}(d b h)\right)}$ & 1.739 & 2.638 & n.a. \\
\hline Fatemi (2011) et al. [40] & StemBark & B. papyrifera & $10^{\left(a+b \times \log _{10}(d b h)\right)}$ & 0.823 & 2.711 & n.a. \\
\hline Fatemi (2011) et al. [40] & Branch & B. papyrifera & $10^{\left(a+b \times \log _{10}(d b h)\right)}$ & 1.476 & 2.195 & n.a. \\
\hline Fatemi (2011) et al. [40] & Leaves & B. papyrifera & $10^{\left(a+b \times \log _{10}(d b h)\right)}$ & 0.622 & 2.485 & n.a. \\
\hline Grote (2003) et al. [22] & TotalAboveground & Q. petraea & $a \times\left((\pi / 4) \times\left(d b h^{2}\right)\right)^{b}$ & 0.131 & 1.316 & n.a. \\
\hline Johansson (1999) [41] & TotalAboveground & P. tremula & $a \times d b h^{b}$ & 0.000146 & 2.604 & n.a. \\
\hline Johansson (1999) [41] & Stem & P. tremula & $a \times d b h^{b}$ & 0.000065 & 2.74 & n.a. \\
\hline Johansson (1999) [41] & Branch & P. tremula & $a \times d b h^{b}$ & 0.000515 & 1.873 & n.a. \\
\hline Johansson (1999) [41] & Leaves & P. tremula & $a \times d b h^{b}$ & 0.000847 & 1.416 & n.a. \\
\hline Johansson \& Karačić (2011) [42] & TotalAboveground & P. nigra $\times P$. doltoides & $a \times d b h^{b}$ & 0.00028 & 2.459 & n.a. \\
\hline Johansson \& Karačić (2011) [42] & Stem & P. nigra $\times P$. doltoides & $a \times d b h^{b}$ & 0.00021 & 2.462 & n.a. \\
\hline Johansson \& Karačić (2011) [42] & Branch & P. nigra $\times P$. doltoides & $a \times d b h^{b}$ & 0.00001 & 2.709 & n.a. \\
\hline Johansson \& Karačić (2011) [42] & Leaves & P. nigra $\times P$. doltoides & $a \times d b h^{b}$ & 0.00042 & 1.926 & n.a. \\
\hline Johansson (1999) [43] & TotalAboveground & B. pendula & $a \times d b h^{b}$ & 0.00087 & 2.286 & n.a. \\
\hline Johansson (1999) [43] & Stem & B. pendula & $a \times d b h^{b}$ & 0.0008 & 2.282 & n.a. \\
\hline Johansson (1999) [43] & Branch & B. pendula & $a \times d b h^{b}$ & 0.00002 & 2.63 & n.a. \\
\hline Johansson (1999) [43] & Leaves & B. pendula & $a \times d b h^{b}$ & 0.004 & 1.12 & n.a. \\
\hline Johansson (1999) [43] & TotalAboveground & B. pubescens & $a \times d b h^{b}$ & 0.00004 & 2.5 & n.a. \\
\hline Johansson (1999) [43] & Branch & B. pubescens & $a \times d b h^{b}$ & 0.00029 & 2.53 & n.a. \\
\hline Johansson (1999) [43] & Leaves & B. pubescens & $a \times d b h^{b}$ & 0.0009 & 1.477 & n.a. \\
\hline Johansson (1999) [43] & Stem & B. pubescens & $a \times d b h^{b}$ & 0.0002 & 2.543 & n.a. \\
\hline Muukkonen (2007) [44] & TotalAboveground & Q. spp. & $\exp (a+((b \times d b h) /(d b h+c)))$ & -0.604 & 10.677 & 15.9 \\
\hline Pastor et al. (1984) [45] & TotalAboveground & P. tremuloides & $a \times d b h^{b}$ & 0.086 & 2.449 & n.a. \\
\hline Pastor et al. (1984) [45] & Stem & P. tremuloides & $a \times d b h^{b}$ & 0.07 & 2.423 & n.a. \\
\hline Pastor et al. (1984) [45] & Branch & P. tremuloides & $a \times d b h^{b}$ & 0.012 & 2.349 & n.a. \\
\hline Rock (2007) [34] & Stem & $P$. tremula $\times P$. tremuloides & $a \times d b h^{b}$ & 0.0197 & 2.764 & n.a. \\
\hline Rock (2007) [34] & Branch & P. tremula $\times P$. tremuloides & $a \times d b h^{b}$ & 0.064 & 2.001 & n.a. \\
\hline Rock (2007) [34] & TotalAboveground & P. tremula $\times P$. tremuloides & $a \times d b h^{b}$ & 0.052 & 2.545 & n.a. \\
\hline Ruark \& Bockheim (1988) [46] & StemWood & P. tremoloides & $\exp (a+b \times \log (d b h))$ & -3.202 & 2.606 & n.a. \\
\hline Ruark \& Bockheim (1988) [46] & StemBark & P. tremoloides & $\exp (a+b \times \log (d b h))$ & -4.532 & 2.552 & n.a. \\
\hline Ruark \& Bockheim (1988) [46] & Branch & P. tremoloides & $\exp (a+b \times \log (d b h))$ & -5.04 & 2.695 & n.a. \\
\hline Ruark \& Bockheim (1988) [46] & Twig & P. tremoloides & $\exp (a+b \times \log (d b h))$ & -5.701 & 1.73 & n.a. \\
\hline this study & TotalAboveground & $P$. tremula $\times P$. tremuloides & $a \times d b h^{b} \times h^{c}$ & 0.021 & 2.084 & 0.936 \\
\hline this study & StemWood & P. tremula $\times$ P. tremuloides & $a \times d b h^{b} \times h^{c}$ & 0.006 & 1.557 & 1.743 \\
\hline this study & StemBark & P. tremula $\times$ P. tremuloides & $a \times d b h^{b} \times h^{c}$ & 0.007 & 1.763 & 0.818 \\
\hline this study & Branch & P. tremula $\times P$. tremuloides & $a \times d b h^{b} \times h^{c}$ & 0.015 & 3.301 & -0.684 \\
\hline this study & TotalAboveground & B. pendula $\times$ B. pubscenes & $a \times d b h^{b} \times h^{c}$ & 0.019 & 1.944 & 1.154 \\
\hline this study & StemWood & B. pendula $\times B$. pubscenes & $a \times d b h^{b} \times h^{c}$ & 0.012 & 1.432 & 1.708 \\
\hline this study & StemBark & B. pendula $\times$ B. pubscenes & $a \times d b h^{b} \times h^{c}$ & 0.098 & 2.088 & -0.486 \\
\hline this study & Branch & B. pendula $\times$ B. pubscenes & $a \times d b h^{b} \times h^{c}$ & 0.001 & 2.862 & 0.779 \\
\hline this study & TotalAboveground & Q. spp. & $a \times d b h^{b} \times h^{c}$ & 0.161 & 2.122 & 0.21 \\
\hline Suchomel et al. (2012) [28] & TotalAboveground & Q. petraea & $a \times d b h^{b}$ & 0.093 & 2.51 & n.a. \\
\hline Telenius (1999) [47] & TotalAboveground & P. tremula $\times P$. tremoloides & $a+b \times d b h^{c}$ & -718.281 & 3.565 & 1.738 \\
\hline Telenius (1999) [47] & TotalAboveground & B. pendula & $a+b \times d b h^{c}$ & 32.317 & 0.329 & 2.328 \\
\hline Tullus et al. (2009) [48] & TotalAboveground & P. tremula $\times P$. tremuloides & $a \times d b h^{b}$ & 107.719 & 2.237 & n.a. \\
\hline Tullus et al. (2009) [48] & Stem & P. tremula $\times P$. tremuloides & $a \times d b h^{b}$ & 61.208 & 2.386 & n.a. \\
\hline Tullus et al. (2009) [48] & Branch & P. tremula $\times P$. tremuloides & $a \times d b h^{b}$ & 23.374 & 2.161 & n.a. \\
\hline Tullus et al. (2009) [48] & BranchNew & P. tremula $\times P$. tremuloides & $a \times d b h^{b}$ & 18.819 & 1.651 & n.a. \\
\hline Uri et al. (2007) [36] & TotalAboveground & B. pendula & $a \times d b h^{b}$ & 142.19 & 2.25 & n.a. \\
\hline Uri et al. (2007) [36] & Stem & B. pendula & $a \times d b h^{b}$ & 118.74 & 2.19 & n.a. \\
\hline Uri et al. (2007) [36] & BranchOld & B. pendula & $a \times d b h^{b}$ & 12.68 & 2.33 & n.a. \\
\hline Uri et al. (2007) [36] & BranchNew & B. pendula & $a \times d b h^{b}$ & 0.93 & 3.25 & n.a. \\
\hline Uri et al. (2007) [36] & Leaves & B. pendula & $a \times d b h^{b}$ & 7.54 & 2.58 & n.a. \\
\hline Wang et al. (2002) [29] & StemWood & P. tremoloides & $a \times d b h^{b}$ & 0.042 & 2.64 & n.a. \\
\hline Wang et al. (2002) [29] & StemBark & P. tremoloides & $a \times d b h^{b}$ & 0.003 & 3.033 & n.a. \\
\hline Wang et al. (2002) [29] & Branch & P. tremoloides & $a \times d b h^{b}$ & 0.001 & 3.161 & n.a. \\
\hline Wang (2006) [49] & Stem & P. davidiana & $10^{(a+b \times \log 10(d b h))}$ & 1.836 & 2.471 & n.a. \\
\hline Wang (2006) [49] & Branch & P. davidiana & $10^{(a+b \times \log 10(d b h))}$ & 0.129 & 3.224 & n.a. \\
\hline Wang et al. (1996) [50] & StemWood & B. papyrifera & $a \times d b h^{b}$ & 0.028 & 2.64 & n.a. \\
\hline Wang et al. (1996) [50] & StemBark & B. papyrifera & $a \times d b h^{b}$ & 0.037 & 2.164 & n.a. \\
\hline Wang et al. (1996) [50] & Branch & B. papyrifera & $a \times d b h^{b}$ & 0.002 & 2.913 & n.a. \\
\hline Wang (2006) [49] & Stem & B. platyphylla & $10^{\left(a+b \times \log _{10}(d b h)\right)}$ & 2.141 & 2.278 & n.a. \\
\hline Wang (2006) [49] & Branch & B. platyphylla & $10^{\left(a+b \times \log _{10}(d b h)\right)}$ & 0.952 & 2.783 & n.a. \\
\hline Zabek \& Prescott (2006) [51] & Stem & P. trichocarpa $\times P$. deltoides & $a \times d b h^{b} \times h^{c}$ & 0.008 & 1.247 & 1.827 \\
\hline Zabek \& Prescott (2006) [51] & Branch & P. trichocarpa $\times P$. deltoides & $a \times d b h^{b} \times h^{c}$ & 0.01 & 1.492 & 1.023 \\
\hline Zell (2008) [52] & TotalAboveground & Q. spp. & $a \times d b h^{b}$ & 0.121 & 2.435 & n.a. \\
\hline
\end{tabular}




\subsection{Stand Density Effects on Tree Height-to-Diameter Ratio in Aspen and Birch Stands}

All information on mean tree height, diameter at breast height, age, and stand density of aspen and birch forests collected from the literature were compiled using a linear mixed-effects model to study the general effect of stand density on the height-to-diameter $(\mathrm{h} / \mathrm{d})$ ratio. Since data on stand density and age were skewed to the right, a log-transformation was applied. The defined two-level mixed-effects model was:

$$
r_{i j k}=\beta_{0}^{(1)}+\beta_{1}^{(1)} \times \log (\text { density })+\beta_{2}^{(1)} \times \log (\text { age })+b_{i}+b_{i j}+\epsilon_{i j k}
$$

with $b_{i} \sim N\left(0, \delta^{2}\right), b_{i j} \sim N\left(0, \kappa^{2}\right)$, and $\epsilon_{i j k} \sim N\left(0, \lambda^{2}\right) . r_{i j k}$ was the mean tree height-to-diameter ratio for trees from sample stand $k$ from species $j$ from study $i$ at given age and density. $\beta_{0}^{(1)}$ denoted the intercept, $\beta_{1}^{(1)}$ was the parameter for density, and $\beta_{2}^{(1)}$ the parameter for tree age. $b_{i}$ was a random effect for tree species $i, b_{i j}$ represented a random effect for study $j$ nested within species $b_{i}$, and $\epsilon_{i j k}$ denoted the residual error.

During the model fitting process no significant fixed effect of the tree genus (aspen, birch) on the height-to-diameter ratio was found and thus it was not included in the model. The tree species effect could not be analysed, because there were too many different species or hybrids of Betula ssp. and Populus ssp. with only few replicates included in the literature based data set.

\subsection{Stand Density Effects on Allocation of Branch Biomass in Aspen and Birch Stands}

The proportion of branch biomass in relation to aboveground woody biomass was provided in some publications. For all other publications, we estimated branch biomass using the provided allometric biomass equations, respectively. For this, 100 values of diameter at breast height were randomly simulated from uniform distributions for each of 16 publications within their range of diameters, respectively.

For each simulated diameter at breast height, biomass of branches and of all other compartments were predicted. Compartment-wise biomass predictions were used to calculate the corresponding aboveground woody biomass for each simulated diameter at breast height. The biomass of leaves was not considered. One allometric biomass equation from the literature used tree height as an additional explanatory variable. In this case, height was predicted according to the mean height-to-diameter ratio ratio given in the publications.

For each prediction, we added a residuum simulated from variance estimates provided. The variance indication was first related to the mean biomass predicted for all trees in a study. The produced relative variance was then used to simulate one residuum from a uniform distribution for each tree of each study. For publications that did not specify any variance, we assumed a compartment-specific global relative variance generalised from all other publications that indicated variance. Hence, the assumed relative variance was $30 \%, 19 \%, 18 \%$, and $25 \%$ of dry mass for branches, stems, stem wood, and stem bark, respectively. The proportion of branch biomass was calculated as the ratio between branch and total aboveground woody biomass. 
We then fitted the mixed-effects logistic regression model:

$$
\Pi_{i j}=\frac{\exp \left(\eta_{i j}\right)}{1+\exp \left(\eta_{i j}\right)},
$$

where $\Pi_{i j}$ was the proportion of branch biomass presented for the stand $j=1, \ldots, n_{i}$ in publication $i=1, \ldots, n$. The linear predictor was:

$$
\begin{aligned}
\eta_{i j}= & \beta_{0}^{(2)}+\beta_{1}^{(2)} \times d b h+\beta_{2}^{(2)} \times \text { density }+\beta_{3}^{(2)} \times \text { age }+\beta_{4}^{(2)} \times \text { density } \times \text { age } \\
& +\beta_{5}^{(2)} \times \text { density } \times d b h+\beta_{6}^{(2)} \times d b h \times \text { density } \times \text { age }+b_{i}+\epsilon_{i j}
\end{aligned}
$$

and contained fixed effects parameters $(\beta)$, a random parameter $b_{i} \sim N\left(0, \tau^{2}\right)$ for the study, and $\epsilon_{i j} \sim N\left(0, \nu^{2}\right)$ as residual error.

\subsection{Allometric Biomass Equations}

Compartment-specific dry mass data were used to fit new allometric biomass equations. Separate models were built for each tree species, individual biomass compartment, and total aboveground woody biomass. The allometric biomass equations were fitted using a non-linear regression least squares approach.

Two types of equations were fitted. In the first type, we used the diameter at breast height as sole explanatory variable (power function):

$$
B M=\beta_{1}^{(3)} \times d b h^{\beta_{2}^{(3)}+\beta_{3}^{(3)} \times I\{s i t e=K\}},
$$

with $B M$ being the compartment specific single tree biomass in kilogram dependent on diameter at breast height $(d b h)$ in centimetres. $\beta_{3}^{(3)}$ was an offset parameter for the study site Kirchberg and was only included when significant at the 5\% level. We used residual standard errors (ResSE) as well as the coefficient of determination $\left(R^{2}\right.$, calculated as one minus residual sum of squares divided by total sum of squares) as a measure of fit.

In the second type of allometric biomass equations tree height was used as an additional explanatory variable:

$$
B M=\beta_{1}^{(4)} \times d b h^{\beta_{2}^{(4)}} \times h e i g h t_{3}^{\beta^{(4)}} .
$$

Allometric biomass equations were also used to examine patterns of biomass allocation in relation to diameter at breast height. Compartment-specific biomass predictions were made for several classes of diameter at breast height, and the proportion of biomass of each compartment relative to the total aboveground woody biomass was calculated cumulatively.

\subsection{Performance of Allometric Models and Comparison with Literature Allometries}

To show how much the biomass estimates of the allometric biomass equation would change if the set of sample trees was a different one, the performance of the fitted allometric models was assessed by means of jackknife resampling in the form of leave-one-out [53,54]. Thus, the model was fitted as many times as observations were available and in each model run a different tree was removed from the sample 
population. The prediction error was then recorded for each specific model run and all errors from all runs were finally used to calculate the root mean squared error. The root mean squared error divided by the mean sample tree biomass yielded the relative root mean squared error.

Additionally, bootstrap resampling was applied in form of 199 random samplings with replacement [53]. Pointwise 95\% credibility intervals were constructed from the empirical distributions resulting from predictions with the 199 curves for a closely spaced grid of diameters at breast height.

Equations obtained from the literature were used to estimate the aboveground woody biomass and the biomass of branches for our sample tree data. If no allometric biomass equations existed for the prediction of aboveground woody biomass, it was calculated as the sum of compartment specific predictions.

Additionally, stand level aboveground woody biomass and branch biomass were estimated. For this, 650 trees were randomly sub-sampled with replacement from our original sample tree data set, and the probability of each tree to be selected into the sub-sample was weighted by the density probability of stand level tree diameters. The biomass of each tree in the sub-sample was then estimated and the total of all trees was regarded stand level biomass. This process was repeated 199 times for each biomass equation from this study and from the literature, respectively.

Eventually, the performance of the allometric biomass equations from the literature was assessed in terms of bias and root mean squared error and was compared with the performance of our new allometric equations for both single tree and stand level estimates.

\subsection{Statistical Analysis}

All data handling, calculations, and statistics were performed using the programming language and statistics package R, version 2.12.0 [55], MASS package [56], nlme package [57] and RODBC package for communication with Microsoft Access database [58].

\section{Results}

\subsection{Study Forests}

Mean tree height varied between 10.9 and $15.5 \mathrm{~m}$ in nurse crops and between 7.7 and $9.0 \mathrm{~m}$ in oak monocultures; the mean height of oaks growing in the understorey of nurse crops was $3.6 \mathrm{~m}$. Accordingly, the mean diameter at breast height varied between 16.9 and $19.4 \mathrm{~cm}$ in nurse crops and between 5.8 and $7.5 \mathrm{~cm}$ in monoculture oaks; the mean diameter at breast height of oaks growing in the understorey of nurse crops was $2.5 \mathrm{~cm}$ (Table 2). 
Table 2. Summary description of stand characteristics; K = Kirchberg, S = Sobernheim.

\begin{tabular}{|c|c|c|c|c|c|c|c|c|c|}
\hline \multirow{3}{*}{ Site } & \multirow{3}{*}{ Species } & \multirow{3}{*}{$\begin{array}{c}\text { Basal Area } \\
\qquad \text { m²/ha }^{2}\end{array}$} & \multirow{3}{*}{$\begin{array}{c}\text { Stand Density } \\
\text { N/ha }\end{array}$} & \multicolumn{3}{|c|}{ dbh } & \multicolumn{3}{|c|}{ Height } \\
\hline & & & & Mean & Min. & Max. & Mean & Min. & Max. \\
\hline & & & & cm & cm & cm & $\mathbf{m}$ & $\mathbf{m}$ & $\mathbf{m}$ \\
\hline \multirow{5}{*}{$\mathrm{K}$} & Aspen & 17.9 & 541.0 & 19.4 & 4.0 & 30.5 & 15.5 & 12.0 & 18.8 \\
\hline & Birch & 13.3 & 481.3 & 17.9 & 2.5 & 31.0 & 12.9 & 9.7 & 15.7 \\
\hline & Oak mono & 22.1 & 4219.3 & 7.5 & 3.0 & 16.0 & 9.0 & 7.1 & 10.3 \\
\hline & Oak under Aspen & 1.5 & 2497.0 & 2.5 & 0.4 & 6.2 & 3.9 & 1.5 & 6.4 \\
\hline & Oak under Birch & 1.5 & 2499.2 & 2.5 & 0.4 & 7.9 & 3.6 & 1.3 & 7.9 \\
\hline \multirow{5}{*}{ S } & Aspen & 10.6 & 445.9 & 16.9 & 7.3 & 23.2 & 13.8 & 10.4 & 16.4 \\
\hline & Birch & 12.8 & 499.8 & 17.4 & 6.0 & 28.0 & 10.9 & 9.2 & 13.0 \\
\hline & Oak mono & 11.8 & 3841.6 & 5.8 & 2.0 & 13.8 & 7.7 & 6.1 & 8.7 \\
\hline & Oak under Aspen & 0.9 & 1664.7 & 2.4 & 0.8 & 5.4 & n.a. & n.a. & n.a. \\
\hline & Oak under Birch & 0.9 & 1665.0 & 2.5 & 0.6 & 5.5 & n.a. & n.a. & n.a. \\
\hline
\end{tabular}

\subsection{Stand Density Effects}

A linear mixed-effects model [Equation (1)] revealed significant effects of stand density and age on the height-to-diameter ratio. The parameter estimate for $\beta_{1}^{(1)}$ for the $\log$ of stand density was 18.366 ( $p<$ $0.001)$, for $\beta_{2}^{(1)}$ for the $\log$ of tree age was $-12.342(p<0.05)$, and for $\beta_{0}^{(1)}$ for the intercept was 15.027 (n.s.). The model included random effects at the tree species level (0.004) and at the study level nested within the tree species level (9.693). Hence, the height-to-diameter ratio was positively correlated with stand density but negatively with tree age (Figure 1).

Figure 1. Relationship between height-to-diameter (h/d) ratio and stand density (N/ha) for a selection of stand ages according to data compiled from the literature [Equation (1)].

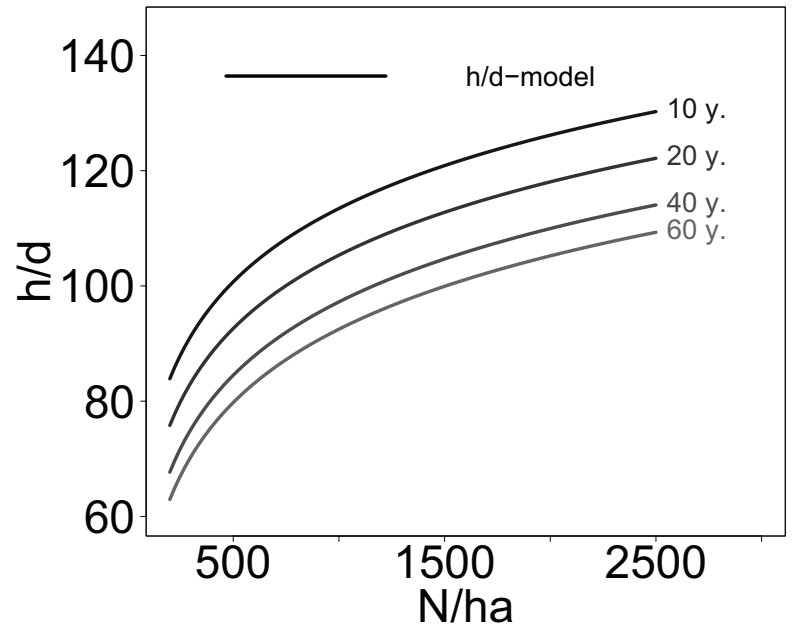


Model 2 and 3 identified dbh, density, age, and interactions of density with age as well as density with $d b h$ to significantly affect the allocation of biomass into branches $(p<0.001)$. Parameter estimates were $\beta_{0}^{(2)}=-1.0666, \beta_{1}^{(2)}=0.0049, \beta_{2}^{(2)}=0.000033, \beta_{3}^{(2)}=-0.01967, \beta_{4}^{(2)}=-0.0000031$, $\beta_{5}^{(2)}=-0.0000067$, and $\beta_{6}^{(2)}=0.0000003$. The standard deviation of the random effect at study level was 0.389 and the overall residual standard error was 0.129 (Figure 2).

Figure 2. Relationship between allocation of biomass and diameter at breast height (dbh, top), stand density (N/ha, middle), or tree age (bottom) [Equation (2)].
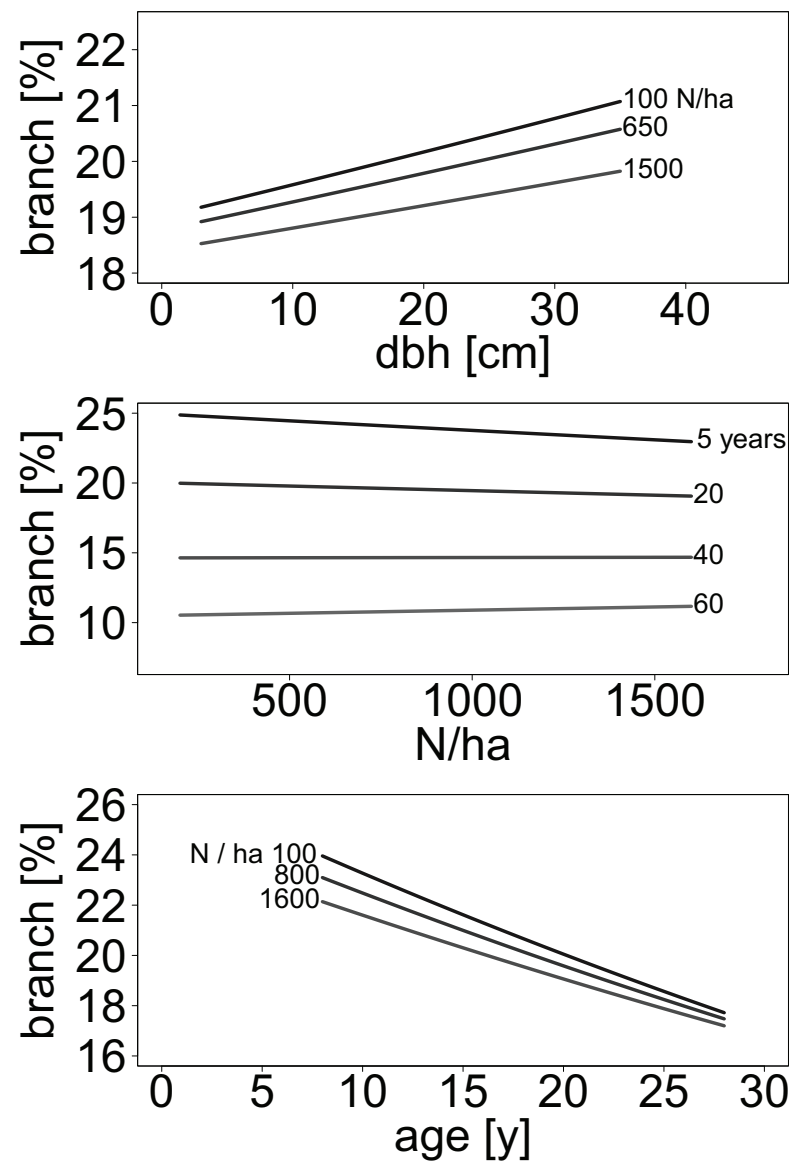

\subsection{Allometric Biomass Equations and Analysis of Model Performance}

The residual standard errors produced by allometric biomass equations using diameter at breast height as explanatory variable ranged between 1 and $13 \mathrm{~kg}$ (Table 3, Figure 3). Models including tree height as an additional explanatory variable reduced residual standard errors especially for stem wood but also for aboveground woody biomass (Table 4, Figure 4). 


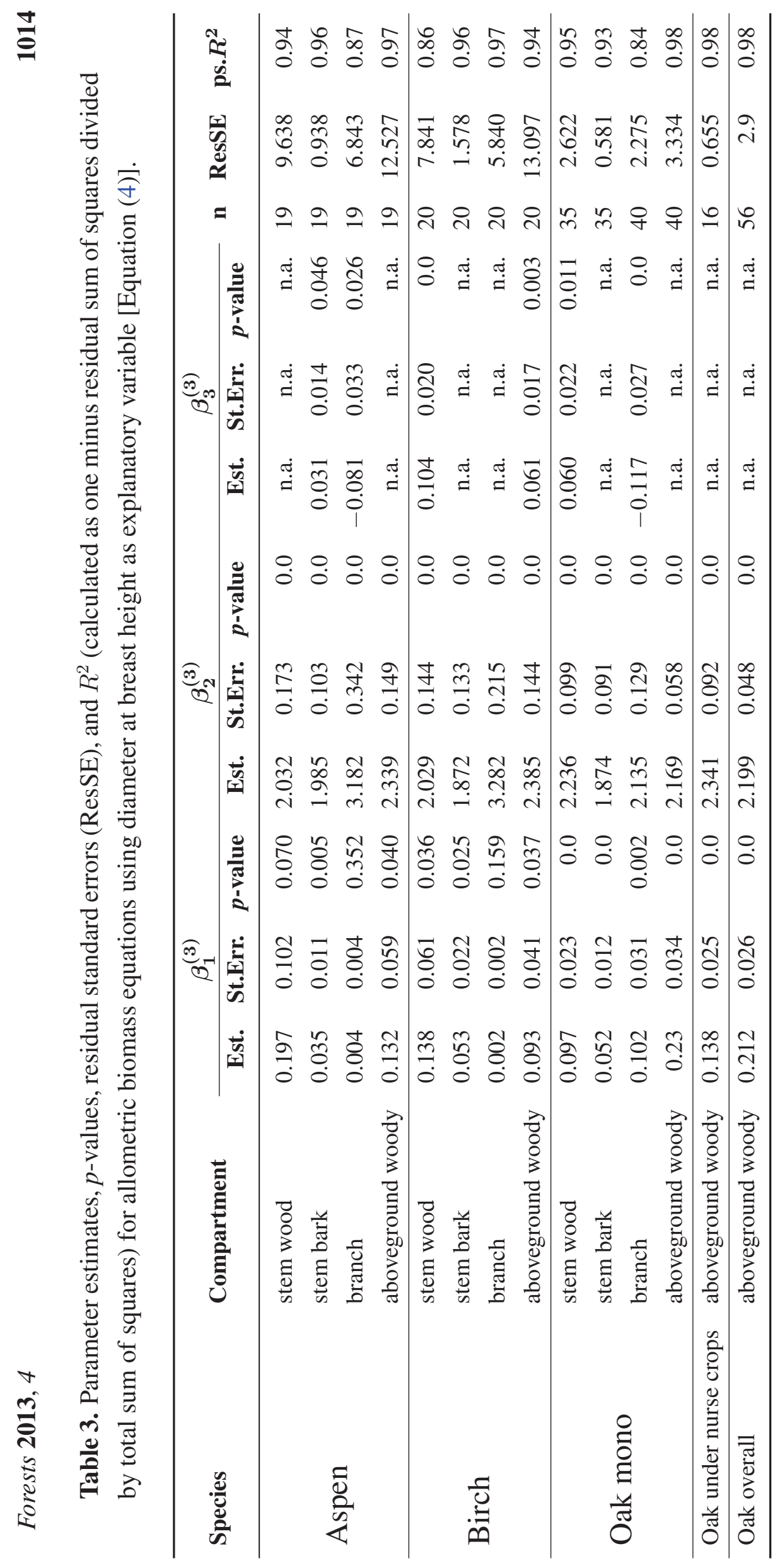


Figure 3. Allometric biomass equations for aspen, birch, and monoculture oak using diameter at breast height as explanatory variable; models with site effect (K \& S) [Equation (4)] were plotted separately. Pointwise $95 \%$ credibility intervals (ci) were calculated from bootstrap resampling.
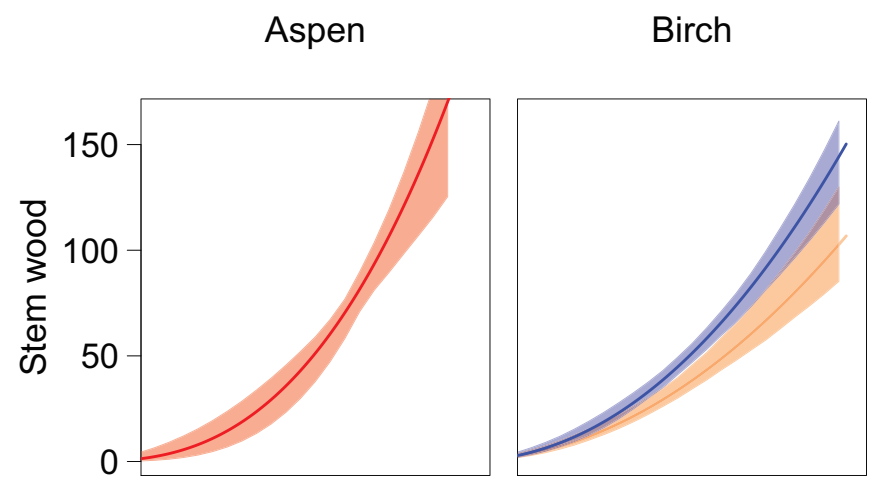

Oak mono
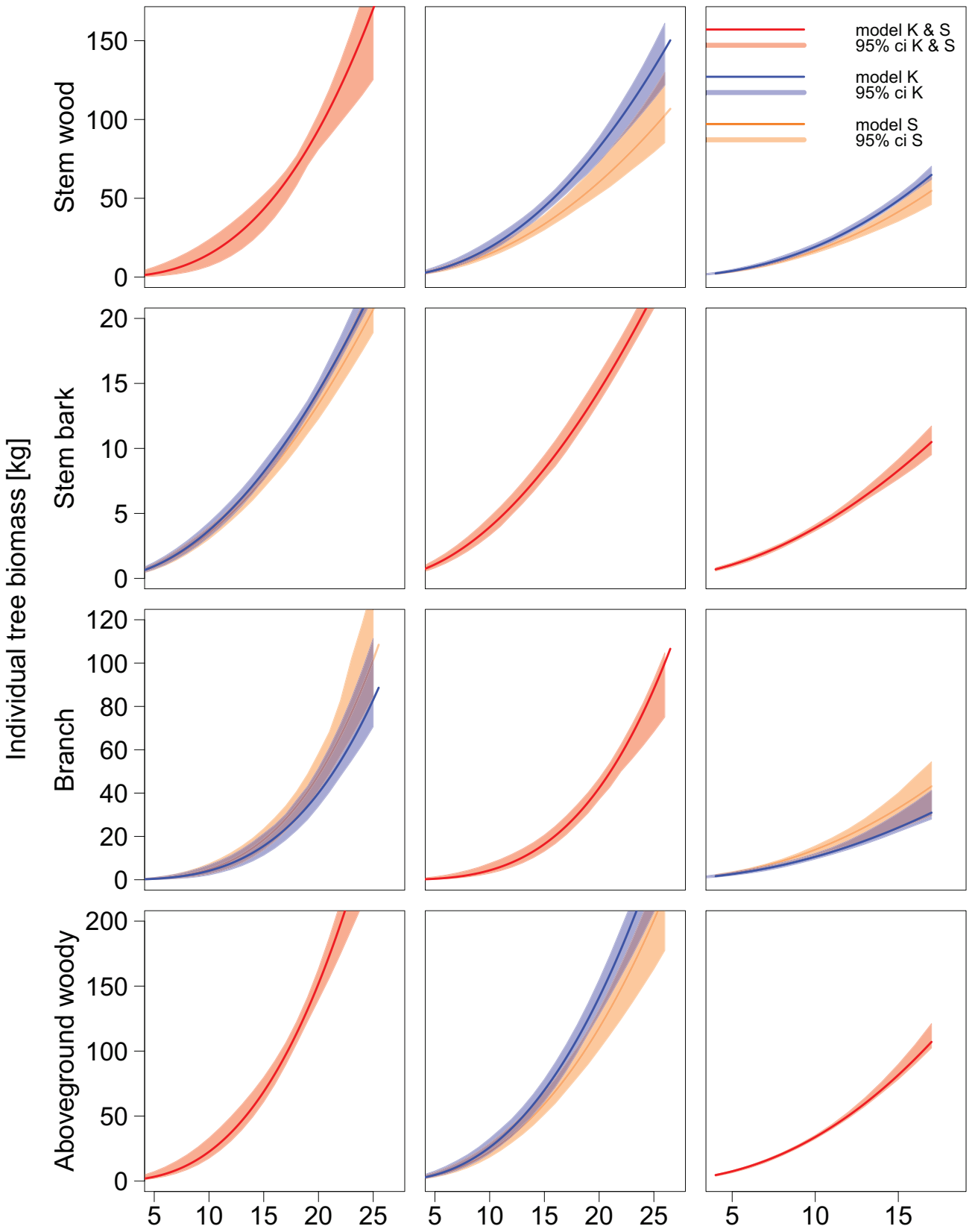

$\mathrm{dbh}[\mathrm{cm}]$ 
$\stackrel{0}{\Xi}$

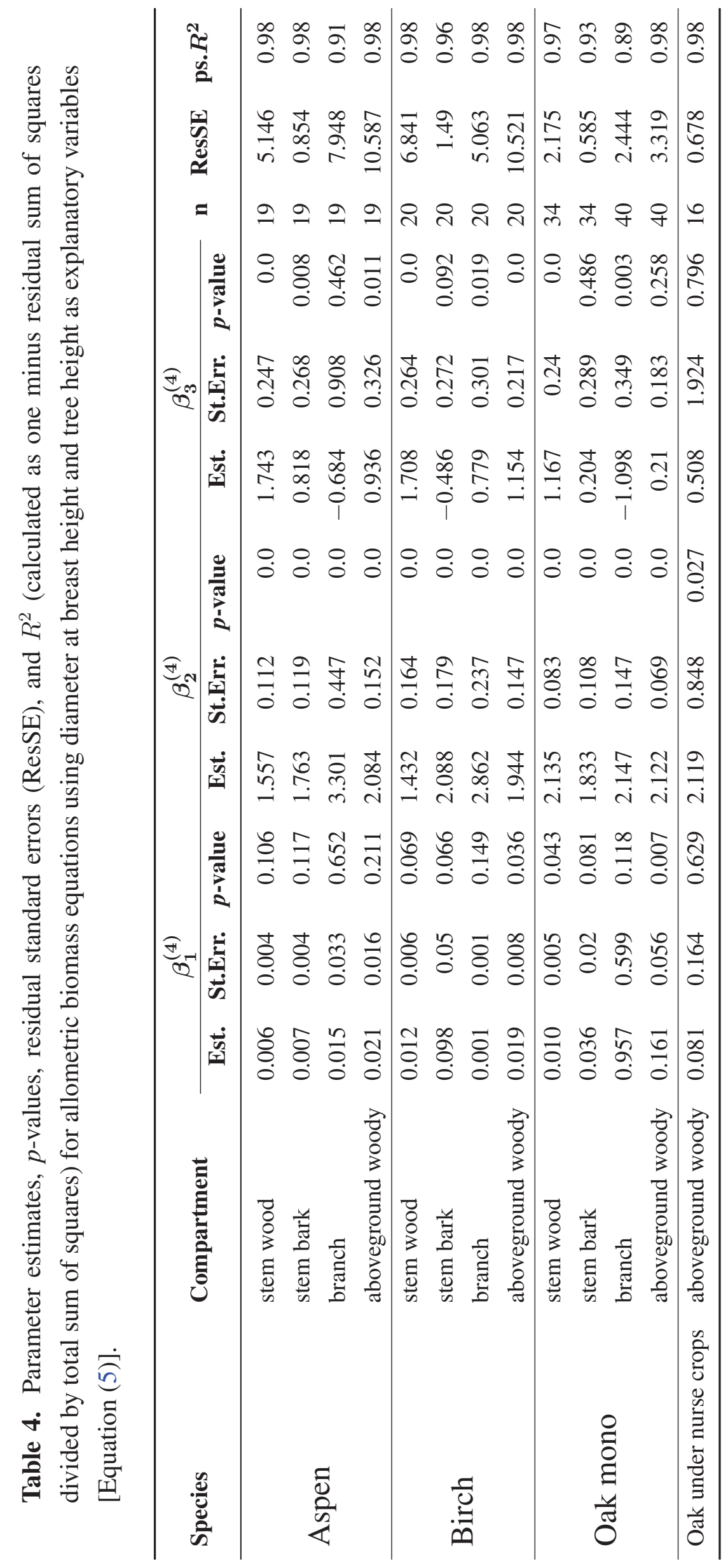


Figure 4. The behaviour of allometric biomass equations for aboveground woody biomass using diameter at breast height ( $\mathrm{dbh}$ ) and tree height (h) as explanatory variables [Equation (5)]. (Left) Predictions of aboveground woody biomass [kg] plotted versus diameter at breast height $[\mathrm{cm}]$ at a selection of fixed heights [m]; (Right) Predictions of aboveground woody biomass plotted versus height at a selection of fixed diameters at breast height. Blue line sections indicate the data range, orange parts indicate the extrapolation range. Points represent empirical aboveground woody biomass data.

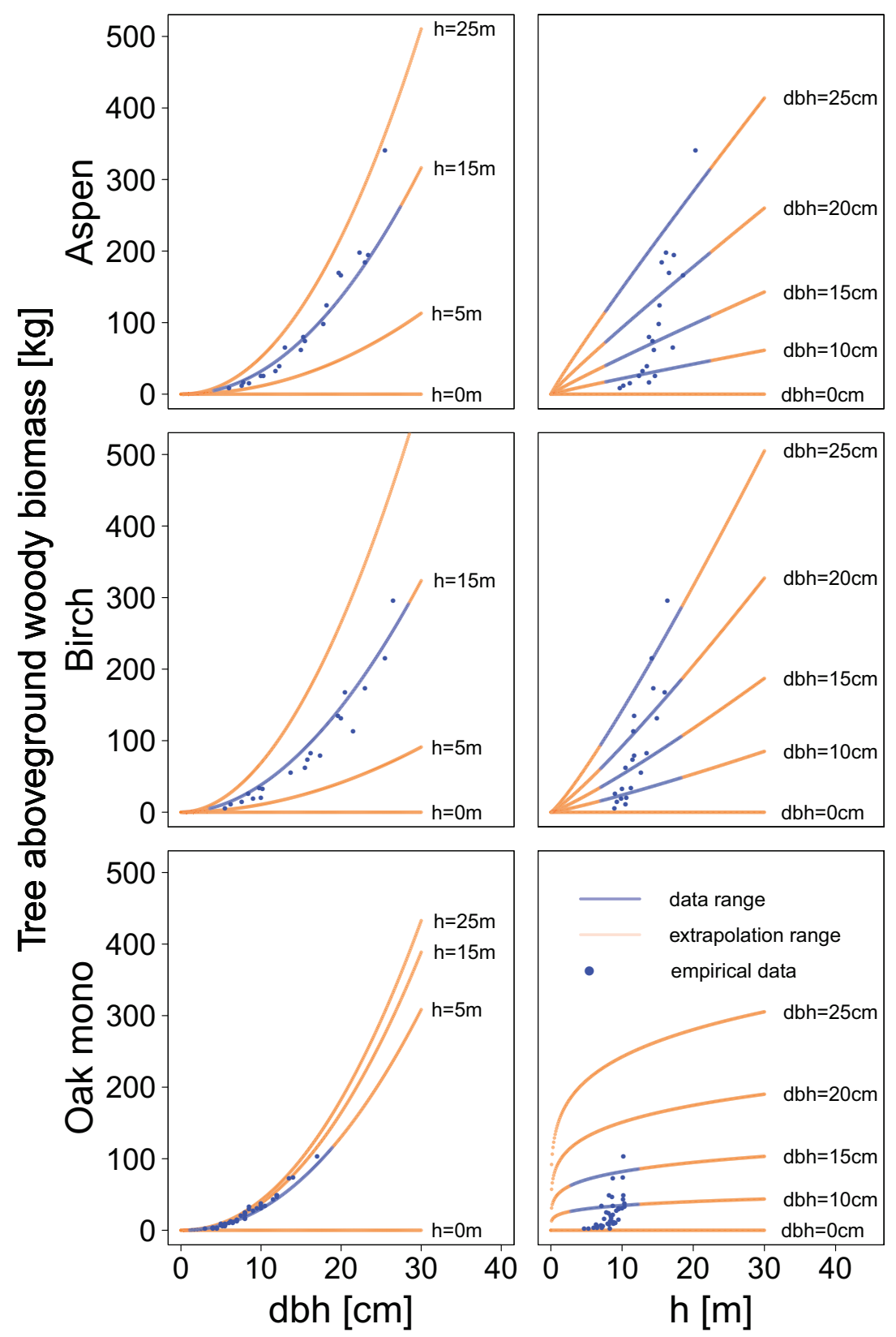


The relative root mean squared error produced by allometric biomass equations using diameter at breast height as the only explanatory variable ranged between $18 \%$ and $20 \%$ for stem wood, between $23 \%$ and $37 \%$ for branches, and between $16 \%$ and $20 \%$ for the aboveground woody biomass (Table 5). The relative root mean squared errors produced by allometric biomass equations using diameter at breast height and tree height had approximately the same range but never exceeded $18 \%$ for stem wood and $16 \%$ for aboveground woody biomass (Table 6).

Confidence intervals based on bootstrap resampling usually increased towards the upper end of the diameter range and could inflate up to $\pm 25 \mathrm{~kg}$; they were generally narrowest for stem bark and could be rather wide for stem wood or branches (Figure 3).

The grand mean allocation of biomass into branches of aspen and birch trees varied between approximately $8 \%$ to $38 \%$ and was negatively correlated with the diameter at breast height. In contrast, the allocation of branch biomass in oaks grown in monoculture remained constant at about $35 \%$ across the entire range of diameters at breast height (Figure 5).

Table 5. Performance of our new allometric biomass equations using diameter at breast height as sole explanatory variable [Equation (4)]; absolute (RMSE) and relative (rel.RMSE) root mean squared errors were calculated for all models from jackknife resampling.

\begin{tabular}{llcc}
\hline Species & Compartment & RMSE & rel. RMSE [\%] \\
\hline \multirow{3}{*}{ Aspen } & stem wood & 10.4 & 20.0 \\
& stem bark & 1.1 & 13.6 \\
& branch & 8.6 & 36.6 \\
& aboveground woody & 13.9 & 16.7 \\
\hline \multirow{3}{*}{ Birch } & stem wood & 9.5 & 19.7 \\
& stem bark & 1.6 & 16.7 \\
& branch & 6.8 & 23.3 \\
Oak & aboveground woody & 16.8 & 19.3 \\
\hline Oak under nurse crop & stem wood & 2.7 & 18.4 \\
& aboveground woody & 1.0 & 18.9 \\
\hline Oak overall & stem bark & 0.6 & 32.9 \\
\hline
\end{tabular}


Table 6. Performance of our new allometric biomass equations using diameter at breast height and tree height as explanatory variables [Equation (5)]; absolute (RMSE) and relative (rel.RMSE) root mean squared errors were calculated for all models by means of jackknife resampling.

\begin{tabular}{llcc}
\hline Species & Compartment & RMSE & rel. RMSE [\%] \\
\hline \multirow{3}{*}{ Aspen } & stem wood & 6.0 & 11.6 \\
& stem bark & 1.0 & 12.2 \\
& branch & 9.7 & 41.3 \\
& aboveground woody & 12.4 & 14.8 \\
\hline \multirow{3}{*}{ Birch } & stem wood & 8.8 & 18.2 \\
& stem bark & 1.8 & 18.3 \\
& branch & 6.2 & 21.3 \\
Oak mono & aboveground woody & 13.6 & 15.5 \\
\hline Oak under nurse crop & stem wood & 2.3 & 15.5 \\
& stem bark & 0.6 & 20.5 \\
& branch & 3.1 & 35.2 \\
& aboveground woody & 4.0 & 16.5 \\
\hline
\end{tabular}

Figure 5. Allocation of biomass across a range of diameters at breast height (dbh) and specified for the biomass compartments stem wood, stem bark, and branches as a fraction of total aboveground woody biomass. Data were estimated using the allometric biomass equations fitted to our sample tree data.
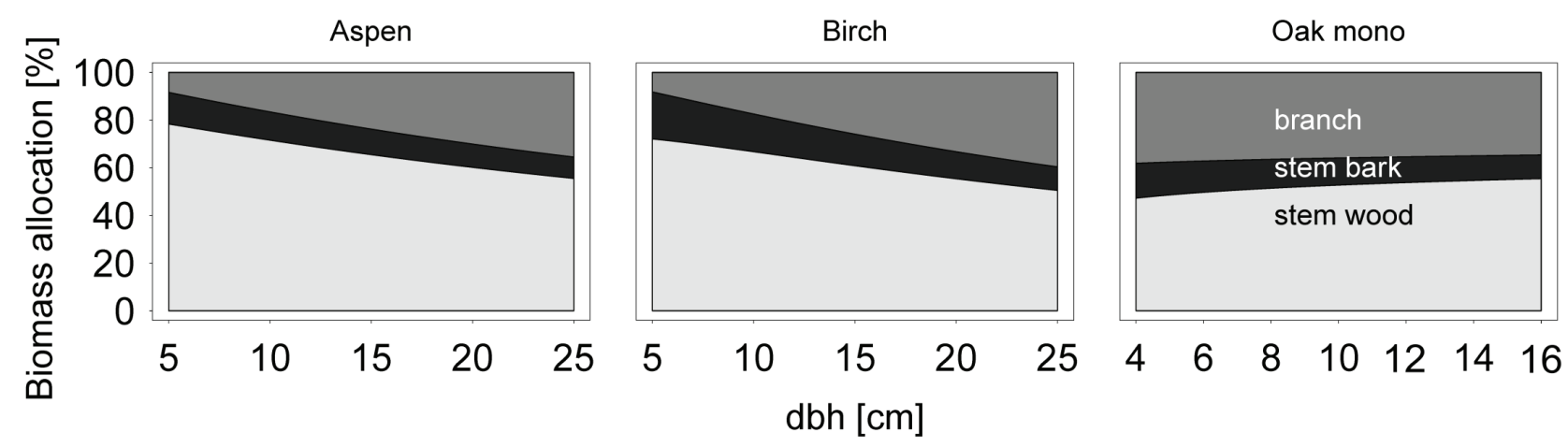


\subsection{Comparison with Other Studies}

Most allometric biomass equations from the literature (Table 1) produced a considerably larger bias and in all cases larger root mean squared errors compared to allometric biomass equations developed in this study (Table 7).

Regarding root mean squared errors calculated for aboveground woody biomass estimates of aspen trees, the allometric biomass equations provided by Ruark \& Bockheim (1988) [46] and Wang (2006) [49] performed closest to the allometric biomass equations developed in this study (Figure 6). Their relative root mean squared error ranged between $19 \%$ and $21 \%$, and was thus $40 \%$ to $50 \%$ higher compared to the root mean squared error produced by allometric biomass equations developed in this study. With respect to branch biomass all equations from the literature produced at least $18 \mathrm{~kg}$ and thus $150 \%$ larger root mean squared errors than equations developed in this study [49].

Out of all allometric biomass equations for birch those by Wang (2006) [49] and Uri et al. (2007) [36] produced a bias of $12 \mathrm{~kg}$ and relative root mean squared errors of $24 \%$ and $26 \%$, which was $110 \%$ and $140 \%$ higher than the root mean squared error of our allometric biomass equations. Estimating branch biomass, the root mean squared errors produced by Wang (2006) [49] were by far smallest among equations from the literature and $60 \%$ larger compared to the error produced by equations developed in this study.

Regarding allometric biomass equation for oak, the equations published by Zell (2008) [52] produced a similar bias and a 31\% larger root mean squared error compared to allometric biomass equations developed in this study, respectively. All other equations produced larger errors; the overall largest bias was $73 \mathrm{~kg}$ and the largest relative root mean squared error was $106 \%$ when predicting the biomass of aspen trees [47].

The root mean squared errors for aboveground woody biomass estimates at stand level were generally lower compared to tree level estimates (Table 8). Errors produced by equations from the literature decreased in four cases below the $10 \%$ level but in most other cases remained larger than $30 \%$ or even $50 \%$ in the case of branch biomass etimates; root mean squared errors produced by equations from the literature at stand level were thus $30 \%$ to $660 \%$ larger than the errors produced by our equations (Table 8). 
$\bar{\Xi}$

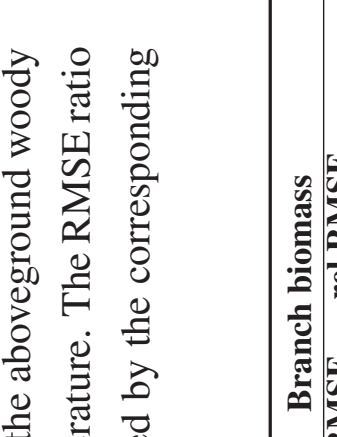

,

$\exists$

\%

흘 馬

ฮี

渮

宅 气ิ

흐를

क्षे

है

हूँ

흘

专

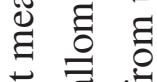

००

II

$\sum^{n}$

농

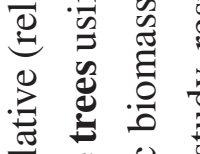

D

吉言

$\sum_{\alpha}^{\infty}$

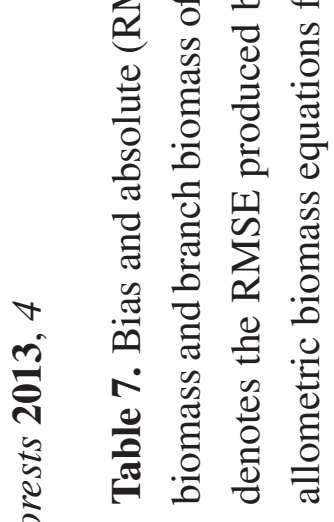

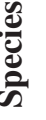

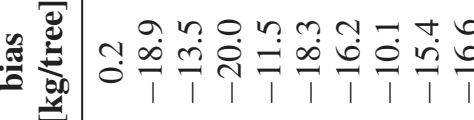

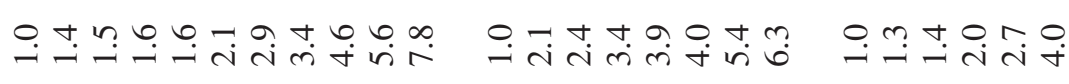

.

을

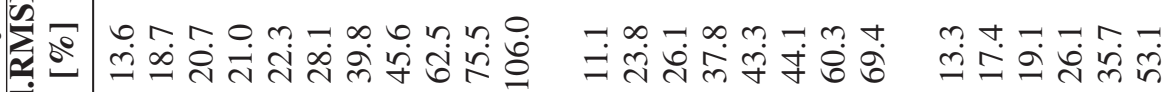

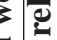

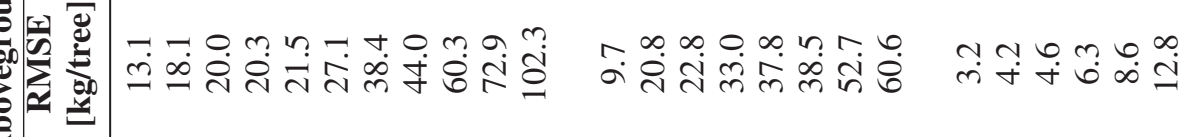

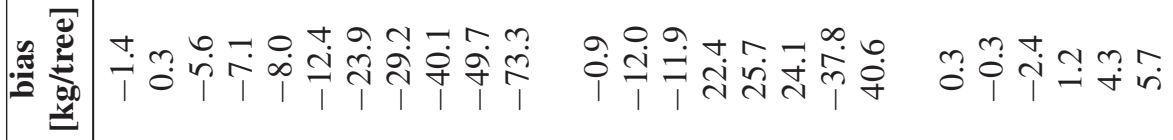

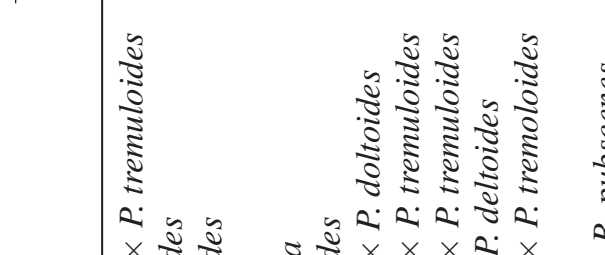

कू.

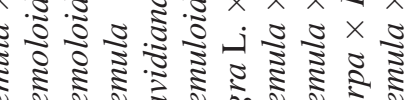

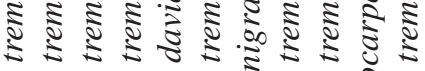

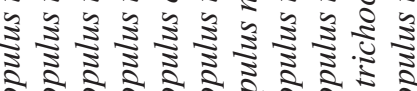

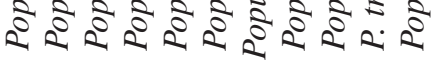

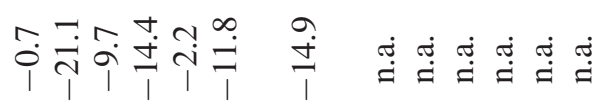

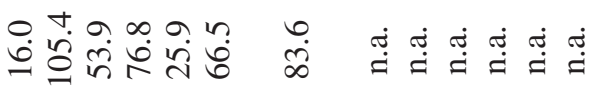
r.

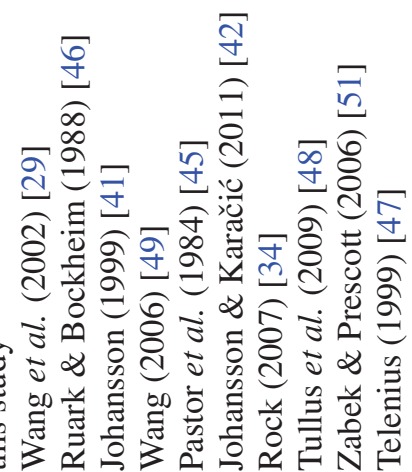

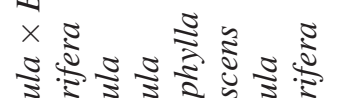

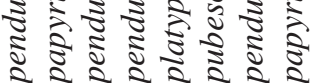

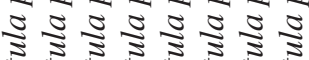

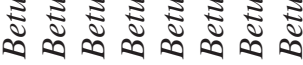
교 क 巳

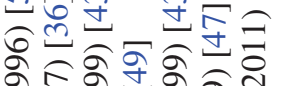

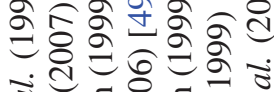

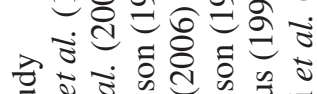

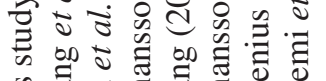

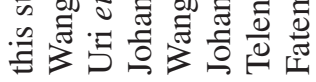

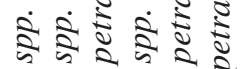

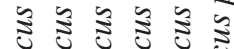

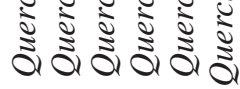

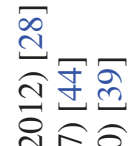
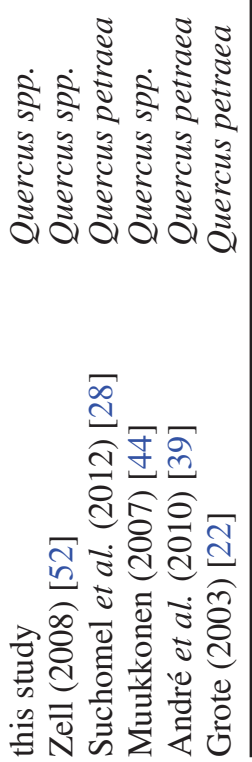
콩

苂

를

స

苞

늠

.

造

¿ ठู

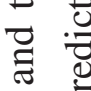

ఖ

를

苛

范

㫯

苂

E

귱 긍

를 울

宓

苋

ㅎํ류

先
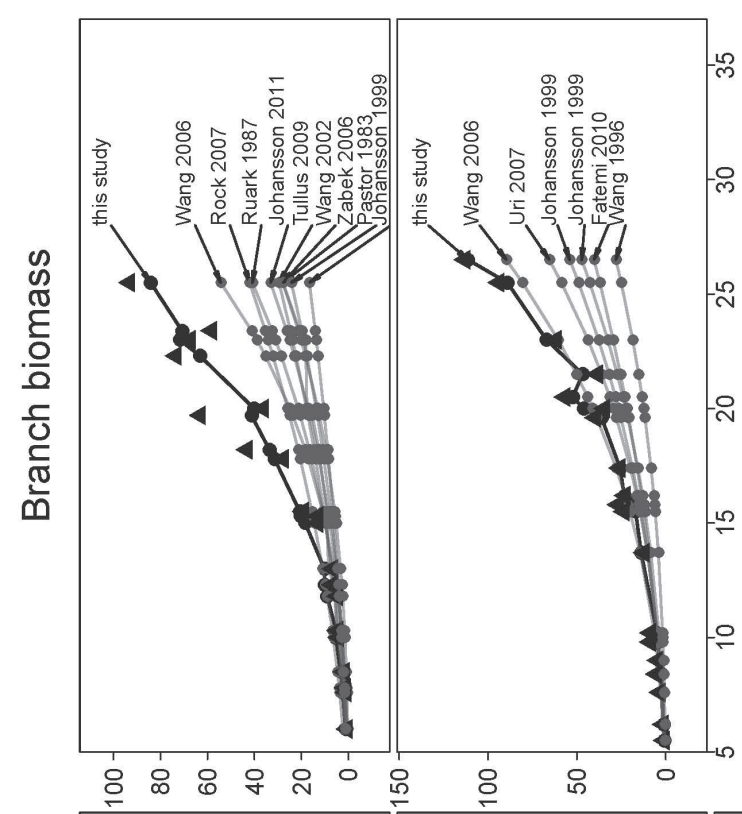

$\bar{\varepsilon}$

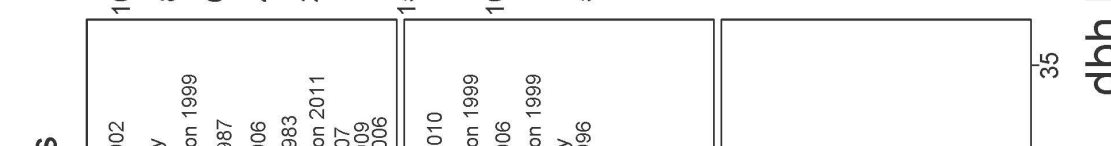

is

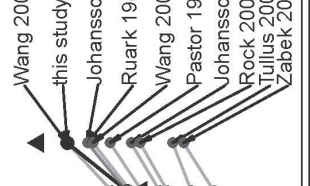

중

잉

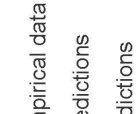

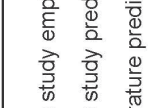

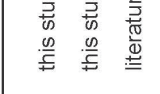

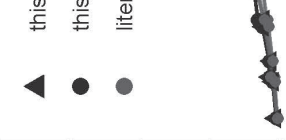

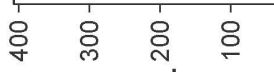

$$
\text { uəds } \forall
$$

$\circ 8$

[б지 ssemo!̣ әәц

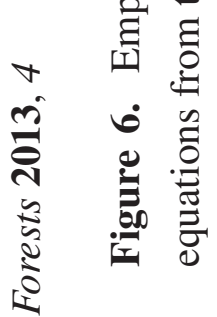


ڤ

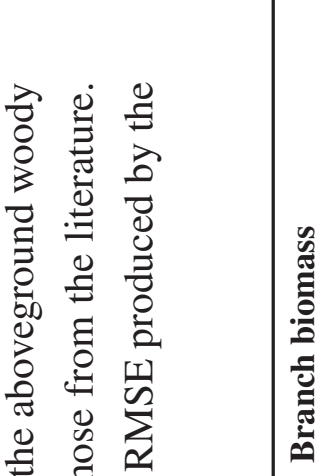

on

$\Rightarrow$

矛 气

흐

ब

党

응

¿.

它

उ

壳总言

ㅎํ छे ?

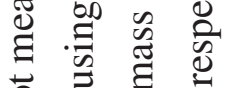

茟

II

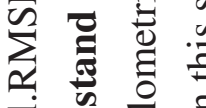

क्ष

吾合总

离

卷言

䠌言瓷

$\sum_{0}^{\infty} \sum_{0}^{\infty}$

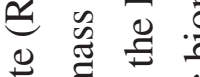

离

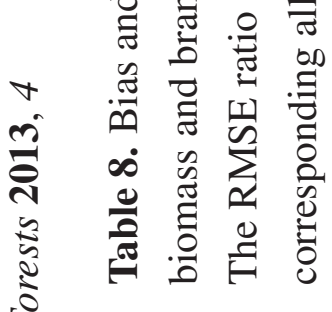

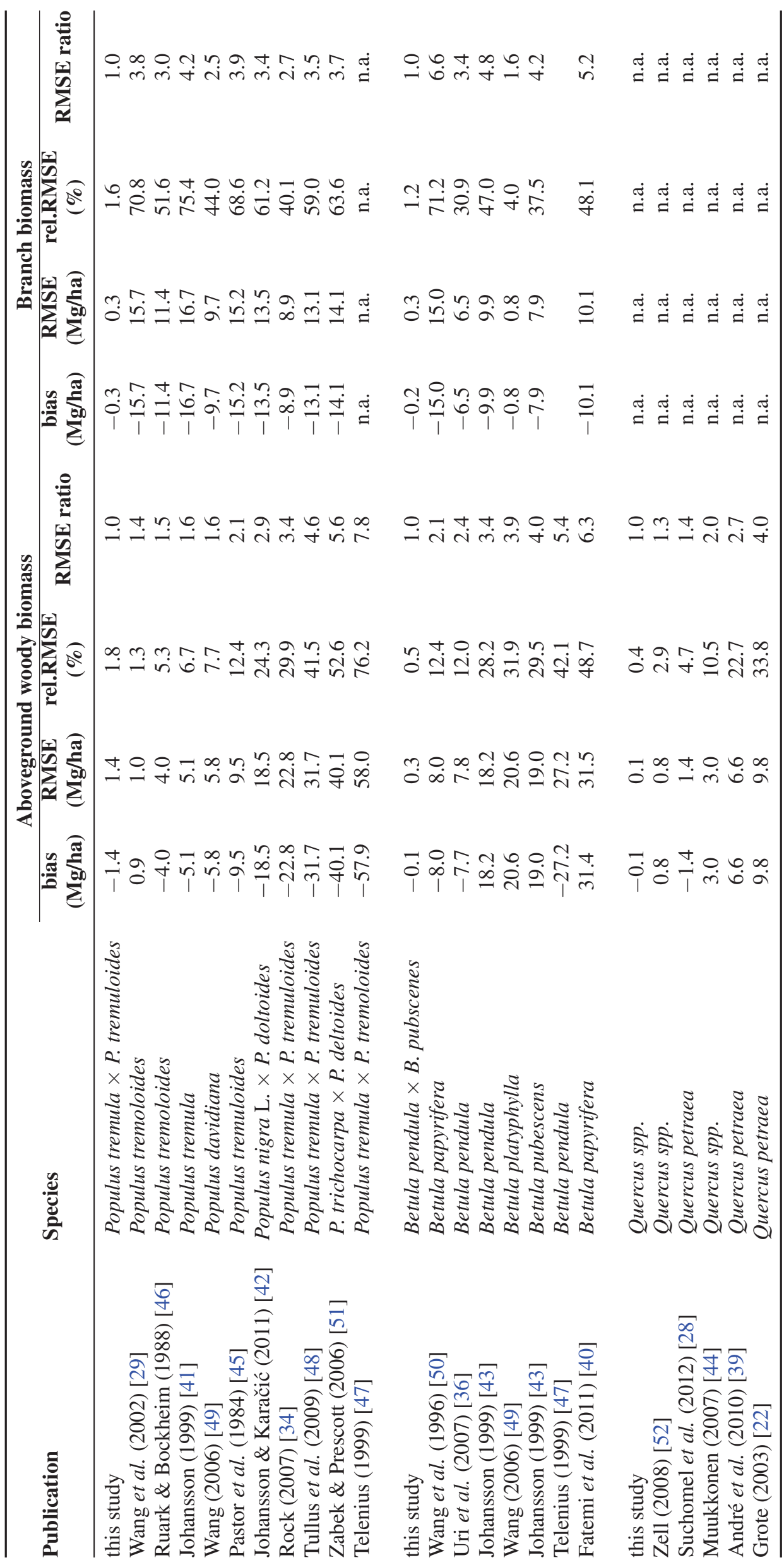




\section{Discussion and Conclusions}

\subsection{Effects of Stand Density and Tree Age on Allometric Relationships of Trees}

In accordance with the findings of other studies $[20,27,59,60]$ our results suggested that the heightto-diameter ratio of aspen and birch individuals significantly increases with increasing stand density. However, height-to-diameter ratio was also affected by the age of trees $[61,62]$.

Also, the younger the tree the more biomass was allocated into branches, and this effect was especially pronounced at low stand densities (Figure 2). Similar findings were reported by Sands \& Landsberg (2002) [63] and Neilsen \& Gerrand (1999) [64].

With increasing age, trees generally tend to invest more resources into radial stem growth and reproduction [65] rather than into height growth or the establishment of new branches. Hence, the modelled age dependency in aspen and birch trees is likely related to tree ontogeny $[59,61]$ but also to changes in competition over time.

These findings underline the importance of considering tree age and stand density as important factors influencing allometric relationships of aspen or birch trees [27,34,40,66]. In particular, these findings indicate that allometric biomass equations developed in aspen or birch forests of high stand density would overestimate stem biomass and underestimate branch biomass when applied to forests of low stand density.

Although our models do not comprehensively assess all possible environmental effects on allometric relationships of trees, these results strongly support the development of specific allometric biomass equations for widely spaced nurse crops.

\subsection{Allometric Biomass Equations}

To avoid any bias related to data transformation [67], we employed non-linear least squares to fit power functions to our biomass data $[20,68]$. We fitted power functions using diameter at breast height as the sole explanatory variable, which generally performed well when predicting sample tree biomass.

The performance analysis based on jackknife resampling indicated relative root mean squared errors of up to $37 \%$ for predictions of branch biomass, which was comparable to reports from other studies [28,36,41-43]. However, the relative root mean squared errors for predictions of stem wood and aboveground woody biomass ranged between $11 \%$ and $20 \%$ and were thus considerably lower.

Such rather large errors can be attributed to our sampling scheme [54], because we sampled only one tree per diameter class. Therefore, reducing the set of sample trees by one particular tree during the resampling led to a relative large variation among the individual resampling curves. The variation was particularly high if the largest or smallest tree was removed during resampling. Therefore future efforts to develop or expand allometric equations should ensure that each diameter class is represented by multiple observations, preferably with a bimodal diameter distribution to produce equations of higher precision and robustness.

However, to extend the applicability of our allometric biomass equations to a broader range of stand densities, which for example may affect the proportion of branches and height-to-diameter ratios [27], we provided a second set of allometric biomass equations including tree height as an additional explanatory 
variable. In accordance with other studies, the additional inclusion of tree height in allometric biomass equations could reduce the standard error of estimate particularly for predictions of stem wood and aboveground woody biomass [62,69]. Apart from these examples, the major improvement was the flexibility of such models to account for changing height-to-diameter ratios between our study plots. In contrast, the application of allometric biomass equations exclusively based on diameter at breast height should be restricted to a fixed range of height-to-diameter ratios in order to avoid a possible bias [34].

Stand density induced variation in height-to-diameter ratios may be one reason why most allometric biomass equations from the literature produced a rather large bias and root mean squared error when estimating the aboveground woody biomass of our sample trees. Thus, Table 7 shows that only one equation from the literature was able to produce a smaller bias than the respective equation developed in this study and that all equations from the literature produced $40 \%$ to $680 \%$ larger root mean squared errors per tree estimate than equations developed in this study.

When estimating tree branch biomass, root mean squared errors ranged between $25 \%$ to $116 \%$ and were additionally enlarged by at least $60 \%$ when equations from the literature were employed (Table 7).

Conclusively, a comparably low bias and root mean squared error, together ensuring a high precession of biomass estimatation at tree level, could only be achieved by allometric biomass equations developed in this study (Table 7 and Figure 6).

However, relative errors were somewhat decreased at stand level but in many cases still constituted a considerable proportion of the overall stand biomass. Assuming 650 aspen trees per hectare with a mean tree aboveground woody biomass of $120 \mathrm{~kg}$ and an overall stand level biomass of 78,000 kg, an error equal or larger $15 \%$ as produced by many allometric biomass equations from the literature equals $11,700 \mathrm{~kg}$ and thus represents almost 3 years or $16 \%$ of the rotation length in our study. The respective branch biomass in the example accounts for approximately $23,400 \mathrm{~kg}(30 \%)$ and was often greatly underestimated by at least $40 \%$ or $9360 \mathrm{~kg}$ (Table 8 and Figure 6).

Therefore, considering these errors and the proportion of rotation length and overall biomass yield they represent, increasing the precision of biomass estimation is important to accurately predict the biomass accumulation in a comparatively short production cycle. In addition, it is crucial for the estimation of nutrient removal with biomass harvesting, a critical aspect of the sustainable management of these forests. Any additional error, as for example produced when biomass equations from the literature were employed, might lead to wrong assessments of the impact of biomass and nutrient removal $[19,70]$. This is particularly the case, when the error is largely attributable to inaccurate predictions of branch biomass, which has considerably higher nutrient concentrations than stem biomass [24].

\subsection{General Conclusion}

If nurse crops are to be used more widely to supply additional biomass from forests or from abandoned agricultural lands [36,71], nutrient sustainability will need to be considered, too [33,70]. However, only few studies have established replicate plot trials of nurse crops to examine growth, nutrient cycling, etc. $[13,72,73]$. Here, we provide specific allometric biomass equations for nurse crops as a foundation for the calculation of biomass production and nutrient sequestration. Biomass estimation in nurse crops 
or other widely spaced forests [35] will benefit greatly from the use of allometric biomass equations that can account for stand density effects.

\section{Acknowledgments}

Funding for labour, field work, and lab analysis costs during this study was provided by the Energy Research Foundation (SEf), the Ministry of Science, Research, and the Arts of the German federal state of Baden-Württemberg, and the Research Institute for Forest Ecology and Forestry RhinelandPalatinate (FAWF). The article publication fee was funded by the German Research Foundation (DFG) and the Albert-Ludwigs-University Freiburg. We greatly acknowledge the kind support of Volker \& Kerstin Stark, Tim Steinkraus, Matthias Schmidt, Renate Nitschke, Rüdiger Unseld, Jürgen Huss, and Helmut May.

\section{Conflicts of Interest}

The authors declare no conflict of interest.

\section{References}

1. BMWi (Federal Ministry of Economics and Technology) \& BMU (Federal Ministry for the Environment, Nature Conservation and Nuclear Safety). Energiekonzept für eine Umweltschonende, Zuverlässige und Bezahlbare Energieversorgung / Energy Concept for an Environmentally Friendly, Reliable and Affordable Energy Supply, 2010 (in German). Available online: http://www.bundesregierung.de/Content/DE/_Anlagen/2012/02/energiekonzept-final.pdf? _-_blob=publicationFile (accessed on 3 September 2012).

2. IPCC. IPCC Summary for Policymakers. In IPCC Special Report on Renewable Energy Sources and Climate Change Mitigation. Prepared by Working Group III of the Intergovernmental Panel on Climate Change; Edenhofer, O., Pichs-Madruga, R., Sokona, Y., Seyboth, K., Matschoss, P., Kadner, S., Zwickel, T., Eickemeier, P., Hansen, G., Schlömer, S., von Stechow, C., Eds.; Cambridge University Press: Cambridge, United Kingdom and New York, NY, USA, 2011.

3. Energieholzplantagen in der Landwirtschaft / Energy Wood Plantations on Agricultural Lands; Bemmann, A., Buttler Manning, D., Eds.; Agrimedia: Germany 2013 (in German).

4. Bryan, B.A.; King, D.; Wang, E. Biofuels agriculture: Landscape-scale trade-offs between fuel, economics, carbon, energy, food, and fiber. GCB Bioenergy 2010, 2, 330-345.

5. Wissenschaftlicher Beirat Agrarpolitik beim Bundesministerium für Ernährung, Landwirtschaft und Verbraucherschutz. Nutzung von Biomasse zur Energiegewinnung-Empfehlungen an Die Politik / Use of Biomass for Energy-Policy Recommendations, 2007. Available online: http://pollux.wzw.tum.de/wdl/fileadmin/wdl-datenbank/gutachten/Gutachten_Bioenergie_gesamt. pdf (in German) (accessed on 3 September 2012). 
6. Bauhus, J.; Puettmann, K.J.; Kühne, C. Close-to-Nature Forest Management in Europe: Does It Support Complexity and Adaptability of Forest Ecosystems? In Managing Forests as Complex Adaptive Systems: Building Resilience to the Challenge of Global Change; Messier, C., Puettmann, K.J., Coates, K.D.D., Eds.; Routledge, The Earthscan Forest Library: Abingdon, UK, 2013; pp. 187-213.

7. Nilsson, C.; Stjernquist, I.; Bärring, L.; Schlyter, P.; Jönsson, A.M.; Samuelsson, H. Recorded storm damage in Swedish forests 1901-2000. Forest Ecol. Manag. 2004, 199, 165-173.

8. Schelhaas, M.J.; Nabuurs, G.J.; Schuck, A. Natural disturbances in the European forests in the 19th and 20th centuries. Glob. Chang. Biol. 2003, 9, 1620-1633.

9. Vallauri, D. Restoring Forests After Violent Storms. In Forest Restoration in Landscapes; Mansourian, S., Vallauri, D., Dudley, N., Eds.; Springer: New York, NY, USA, 2005; Chapter 48, pp. 345-350.

10. Unseld, R.; Wenzel, M.; Weich, T.; Stark, H.; Weinreich, A.; Bauhus, J. Energie-Vorwälder in Südwestdeutschland-Alternative Bewirtschaftungsformen zur Steigerung der energetisch nutzbaren Biomasse im Wald / Energy nurse crops-Alternative silviculture systems to increase the supply of biomass for energy purposes in forests. Forst und Holz 2010, 10, 14-17.

11. Energie-Vorwälder-Alternative Bewirtschaftungsformen zur Steigerung der Energetisch Nutzbaren Biomasse Im Wald Durch Integration Von Schnell Wachsenden Baumarten / Energy Nurse Crops-Alternative Silviculture Systems to Increase the Supply of Biomass for Energy Purposes in Forests by Integrating Fast-Growing Tree Species; Unseld, R., Bauhus, J., Eds.; Freiburger Forstliche Forschung: Freiburg, Germany 2013 (in German).

12. Cotta, H. Anweisung zum Waldbau / Instructions for Silviculture; Arnoldsche Buchhandlung: Dresden \& Leipzig, Germany, 1828 (in German).

13. Schmidt-Schütz, A.; Huss, J. Wiederbewaldung von Fichten-Sturmwurffächen auf Vernässenden Standorten mit Hilfe von Pioniergehölzen / Reforestation of Storm Damaged Spruce Stands on Water Logged Sites Using Pioneer Trees; BW-PLUS: Freiburg, Germany, 1998.

14. Carlson, D.W.; Groot, A. Microclimate of clear-cut, forest interior, and small openings in trembling aspen forest. Agric. For. Meteorol. 1997, 87, 313-329.

15. Heger, A. Die Begründung von Mischwäldern auf Großkahlfächen unter Besonderer Berücksichtigung des Vorwaldgedankens / The Establishment of Mixed Forests on Large Barren Areas With Special Emphasis on the Nurse Crop Concept; Neumann Verlag: Radebeul \& Berlin, Germany, 1952 (in German).

16. Langvall, O.; Örlander, G. Effects of pine shelterwoods on microclimate and frost damage to Norway spruce seedlings. Can. J. For. Res. 2001, 31, 155-164.

17. Örlander, G.; Karlsson, C. Influence of shelterwood density on survival and height increment of picea abies advance growth. Scand. J. For. Res. 2000, 15, 20-29.

18. Clark, D.A.; Brown, S.; Kicklighter; D.W.; Chambers J.Q.; Thomlinson, J.R.; Ni, J. Measuring net primary production in forests: Concepts and field methods. Ecol. Appl. 2001, 11, 356-370.

19. Pretzsch, H. Re-Evaluation of Allometry: State-of-the-Art and Perspective Regarding Individuals and Stands of Woody Plants. In Progress in Botany; Lüttge, U., Beyschlag, W., Büdel, B., Francis, D., Eds.; Springer: Berlin/Heidelberg, Germany, 2010; Volume 71, pp. 339-369. 
20. Zianis, D.; Mencuccini, M. On simplifying allometric analyses of forest biomass. For. Ecol. Manag. 2004, 187, 311-332.

21. Ahrends, B.; Meeseberg, H.; Meiwes, K.J.; Rademacher, P. Sensitivität der Nährstoffentzüge aus Waldökosystemen Hinsichtlich der Biomassefunktionen Und Nährstoffgehalte / Sensitivity of the Nutrient Removal From Forest Ecosystems in Terms of Biomass Equations and Nutrient Contents. In Proceedings of the Annual Meeting of the DBG: Böden Verstehen-Böden nutzen—Böden Fit Machen (not peer-reviewed online publication of DBG), Berlin/Potsdam, Germany, 2011.

22. Grote, R.; Schuck, J.; Block, J.; Pretzsch, H. Oberirdische holzige Biomasse in Kiefern-/Buchenund Eichen-/Buchen-Mischbeständen / Aboveground woody biomass in mixed stands of scots pine/common beech and european oak/common beech. Forstwiss. Centralbl. 2003, 122, 287-301. In German.

23. Klinck, U.; Meesenburg, H.; Scheler, B.; Fleck, S.; Wagner, M.; Ahrends, B.; Meiwes, K.J. Nährstoffbilanzen für Buchen-, Eichen-, Fichten- und Kiefernbestände Bei Verschiedenen Nutzungsintensitäten / Nutrient Balances for Beech, Oak, Spruce and Pine Stands at Different Intensities of Use. In Proceedings of the Annual Meeting of the DBG: Böden Verstehen-Böden nutzen-Böden Fit Machen; Berlin/Potsdam, Germany, 2011.

24. Rademacher, P. Nährelementgehalte in den Kompartimenten wichtiger Wirtschaftsbaumarten und deren Bedeutung für die Reststoffverwertung / Contents of nutrient elements in tree components of economically important species in relation to their residual utilisation. Holz als Roh-und Werkst. 2005, 63, 285-296 (in German).

25. Seifert, T.; Schuck, J.; Block, J.; Pretzsch, H. Simulation von Biomasse- und Nährstoffgehalt von Waldbäumen / Simulation of Biomass and Nutrient Content of Forest Trees. In Proceesings of the DVFFA, Section Yield Science, Annual Meeting, Staufen, Germany, 2006.

26. Návar, J. Allometric equations for tree species and carbon stocks for forests of north-western Mexico. For. Ecol. Manag. 2009, 257, 427-434.

27. Ketterings, Q.M.; Coe, R.; van Noordwijk, M.; Ambagau, Y.; Palm, C.A. Reducing uncertainty in the use of allometric biomass equations for predicting above-ground tree biomass in mixed secondary forests. For. Ecol. Manag. 2001, 146, 199-209.

28. Suchomel, C.; Pyttel, P.; Becker, G.; Bauhus, J. Biomass equations for sessile oak (Quercus petraea (Matt.) Liebl.) and hornbeam (Carpinus betulus L.) in aged coppiced forests in southwest Germany. Biomass Bioenerg. 2012, 46, 722-730.

29. Wang, J.R.; Zhong, A.L.; Kimmins, J.P. Biomass estimation errors associated with the use of published regression equations of paper birch and trembling aspen. North. J. Appl. For. 2002, 19, 128-136.

30. Poorter, H.; Niklas, K.J.; Reich, P.B.; Oleksyn, J.; Poot, P.; Mommer, L. Biomass allocation to leaves, stems and roots: Meta-analyses of interspecific variation and environmental control. New Phytol. 2012, 193, 30-50.

31. Thorpe, H.C.; Astrup, R.; Trowbridge, A.; Coates, K.D. Competition and tree crowns: A neighborhood analysis of three boreal tree species. For. Ecol. Manag. 2010, 259, 1586-1596.

32. West, P.W. Growing Plantation Forests; Springer: Berlin/Heidelberg, Germany, 2006. 
33. Sverdrup, H.; Thelin, G.; Robles, M.; Stjernquist, I.; Sörensen, J. Assesing nutrient sustainability of forest production for different tree species considering $\mathrm{Ca}, \mathrm{Mg}, \mathrm{K}, \mathrm{N}$ and $\mathrm{P}$ at Björnstorp Estate, Sweden. Biogeochemistry 2006, 81, 219-238.

34. Rock, J. Suitability of published biomass equations for aspen in Central Europe-Results from a case study. Biomass Bioenergy 2007, 31, 299-307.

35. Drouineau, S.; Laroussinie, O.; Birot, Y.; Terrasson, D.; Formery, T.; Roman-Amat, B. Joint Evaluation of Storms, Forest Vunerability and Their Restoration; European Forest Institute: Joensuu, Finland, 2000.

36. Uri, V.; Lõhmus, K.; Ostonen, I.; Tullus, H.; Lastik, R.; Vildo, M. Biomass production, foliar and root characteristics and nutrient accumulation in young silver birch (Betula pendula Roth.) stand growing on abandoned agricultural land. Eur. J. For. Res. 2007, 126, 495-506.

37. Dept. Waldmonitoring und Umweltvorsorge (Forest Monitoring and Precautionary Environmental Protection), Research Institute for Forest Ecology and Forestry Rhineland-Palatinate (FAWF), Trippstandt, Germany, 2013 (in German); Permanent Plots; Data used in this study are available upon request. Available online: http://www.waldrlp.de/fileadmin/website/fawfseiten/fawf/FUM/index.htm?umweltmonitoring/DBFL/forschung.html (accessed on 20 November 2013).

38. Weinreich, A. Qualitätsentwicklung Junger Eichen in Bestandeslücken / Quality Development of Young Oaks in Gaps. Ph.D. Thesis, Albert-Ludwigs-Universität, Freiburg i. Brsg., Germany, 2000.

39. André, F.; Jonard, M.; Ponette, Q. Biomass and nutrient content of sessile oak (Quercus petraea (Matt.) Liebl.) and beech (Fagus sylvatica L.) stem and branches in a mixed stand in southern Belgium. Sci. Total. Environ. 2010, 408, 2285-2294.

40. Fatemi, F.R.; Yanai, R.D.; Hamburg, S.P.; Vadeboncoeur, M.A.; Arthur, M.A.; Briggs, R.D.; Levine, C.R. Allometric equations for young northern hardwoods: The importance of age-specific equations for estimating aboveground biomass. Can. J. For. Res. 2011, 41, 881-891.

41. Johansson, T. Biomass equations for determining fractions of European aspen growing on abandoned farmland and some practical implications. Biomass Bioenergy 1999, 17, 471-480.

42. Johansson, T.; Karačić, A. Increment and biomass in hybrid poplar and some practical implications. Biomass Bioenergy 2011, 35, 1925-1934.

43. Johansson, T. Biomass equations for determining fractions of pendula and pubescent birches growing on abandoned farmland and some practical implications. Biomass Bioenergy 1999, 16, 223-238.

44. Muukkonen, P. Generalized allometric volume and biomass equations for some tree species in Europe. Eur. J. For. Res. 2007, 126, 157-166.

45. Pastor, J.; Aber, J.D.; Melillo, J.M. Biomass prediction using generalized allometric regressions for some northeast tree species. For. Ecol. Manag. 1984, 7, 265-274.

46. Ruark, G.A.; Bockheim, J.G. Biomass, net primary production, and nutrient distribution for an age sequence of Populus tremuloides ecosystems. Can. J. For. Res. 1988, 18, 435-443.

47. Telenius, B.F. Stand growth of deciduous pioneer tree species on fertile agricultural land in southern Sweden. Biomass Bioenergy 1999, 16, 13-23. 
48. Tullus, A.; Tullus, H.; Soo, T.; Pärn, L. Above-ground biomass characteristics of young hybrid aspen (Populus tremula L. $\times$ P. tremuloides Michx.) plantations on former agricultural land in Estonia. Biomass Bioenergy 2009, 33, 1617-1625.

49. Wang, C. Biomass allometric equations for 10 co-occuring tree species in Chinese temperate forests. For. Ecol. Manag. 2006, 222, 9-16.

50. Wang, J.R.; Zhong, A.L.; Simard, S.W.; Kimmis, J.P. Aboveground biomass and nutrient accumulation in an age sequence of paper birch Betula papyrifera in the Interior Cedar Hemlock zone, British Columbia. For. Ecol. Manag. 1996, 83, 27-38.

51. Zabek, L.M.; Prescott, C.E. Biomass equations and carbon content of aboveground leafless biomass of hybrid poplar in Coastal British Columbia. For. Ecol. Manag. 2006, 223, 1-3, 291-302.

52. Zell, J. Methoden für die Ermittlung, Modellierung und Prognose der Kohlenstoffspeicherung in Wäldern auf Grundlage Permanenter Großrauminventuren / Methodologies for the Identification, Modeling and Prediction of Carbon Storage in Forests Based on Permanent Large-Scale Surveys. Ph.D. Thesis, University of Freiburg, Freiburg, Germany, 2008 (in German).

53. Crowley, P.H. Resampling methods for computation-intensive data analysis in ecology and evolution. Annu. Rev. Ecol. Syst. 1992, 23, 404-447.

54. Chave, J; Condit, R.; Aguilar, S.; Hernandez, A.; Lao, S.; Perez, R.; Error propagation and scaling for tropical forest biomass estimates. Phil. Trans. R. Soc. Lond. B 2004, 359, 409-420.

55. R Development Core Team. $\quad R:$ A Language and Environment for Statistical Computing; $\mathrm{R}$ Foundation for Statistical Computing: Vienna, Austria, 2010. Available online: http://www.R-project.org/ (accessed on 14 September 2012).

56. Venables, W.N.; Ripley, B.D. Modern Applied Statistics with S, 4th ed.; Springer: New York, NY, USA, 2002.

57. Pinheiro, J.; Bates, D.; DebRoy, S.; Sarkar, D.; The R Development Core Team. NLM: Linear and Nonlinear Mixed Effects Models, R Package Version 3.1-98., 2011. Available online: http://CRAN.R-project.org/package=nlme (accessed on 14 September 2012).

58. Ripley, B.; Lapsley, M. RODBC: ODBC Database Access. R Package Version 1.3-3, 2011. Available online: http://CRAN.R-project.org/package=RODBC (accessed on 14 September 2012).

59. Niklas, K.J. Plant Allometry: The Scaling of Form and Process; University of Chicago Press: Chicago, IL, USA, 1994.

60. Návar, J.; Ríos-Saucedo, J.; Pérez-Verdín, G.; de Jesús Rodríguez-Flores, F.; Domínguez-Calleros, P.A. Regional aboveground biomass equations for North American arid and semi-arid forests. J. Arid Environ. 2013, 97, 127-135.

61. Bond-Lamberty, B.; Wang, C.; Gower, S.T. Aboveground and belowground biomass and sapwood area allometric equations for six boreal tree species of northern Manitoba. Can. J. For. Res. 2002, $32,1441-1450$.

62. Antonio, N.; Tom, M.; Tom, J.; Soares, P.; Fontes, L. Effect of tree, stand, and site variables on the allometry of Eucalyptus globulus tree biomass. Can. J. For. Res. 2007, 37, 895-906.

63. Sands, P.J.; Landsberg, J.J. Parameterisation of 3-PG for plantation grown Eucalyptus globulus. For. Ecol. Manag. 2002, 163, 273-292. 
64. Neilsen, W.A.; Gerrand, A.M. Growth and branching habit of Eucalyptus nitens at different spacing and the effect on final crop selection. For. Ecol. Manag. 1999, 123, 217-229.

65. Bazzaz, F.A.; Grace, J. Plant Ressource Allocation; Academic Press: London, UK, 1997.

66. Pretzsch, H.; Biber, P. A re-evaluation of Reineke's rule and stand density index. For. Sci. 2005, 51, 304-320.

67. Sprugel, D.G. Correcting for bias in log-transformed allometric equations. Ecology 1983, 64, 209-210.

68. Ter-Mikaelian, M.T.; Korzukhin, M.D. Biomass equations for sixty-five North American tree species. For. Ecol. Manag. 1997, 97, 1-24.

69. Parresol, B.R. Assessing tree and stand biomass: A review with examples and critical comparisons. For. Sci. 1999, 45, 573-593.

70. Ranger, J.; Turpault, M.P. Input-output nutrient budgets as a diagnostic tool for sustainable forest management. For. Ecol. Manag. 1999, 122, 139-154.

71. Consequences of Land Use Changes, Advances in Ecological Sciences 5; Mander, Ü., Jongman, R.H.G., Eds.; Wessex Institute of Technology Press: Boston, MA, USA, 2000.

72. Maard, H. Stratified mixture of young Norway spruce and birch as an alternative to pure stands of Norway spruce. Acta Univ. Agric. Suec. Silvestria 1997, 35, 713-722.

73. Bergqvist, G. Wood volume yield and stand structure in Norway spruce understorey depending on birch shelterwood density. For. Ecol. Manag. 1999, 122, 221-229.

(C) 2013 by the authors; licensee MDPI, Basel, Switzerland. This article is an open access article distributed under the terms and conditions of the Creative Commons Attribution license (http://creativecommons.org/licenses/by/3.0/). 